\title{
"Low-For-Long" Interest Rates and Banks' Interest Margins and Profitability: Cross-Country Evidence
}

Claessens, Stijn, Nicholas Coleman, and Michael Donnelly
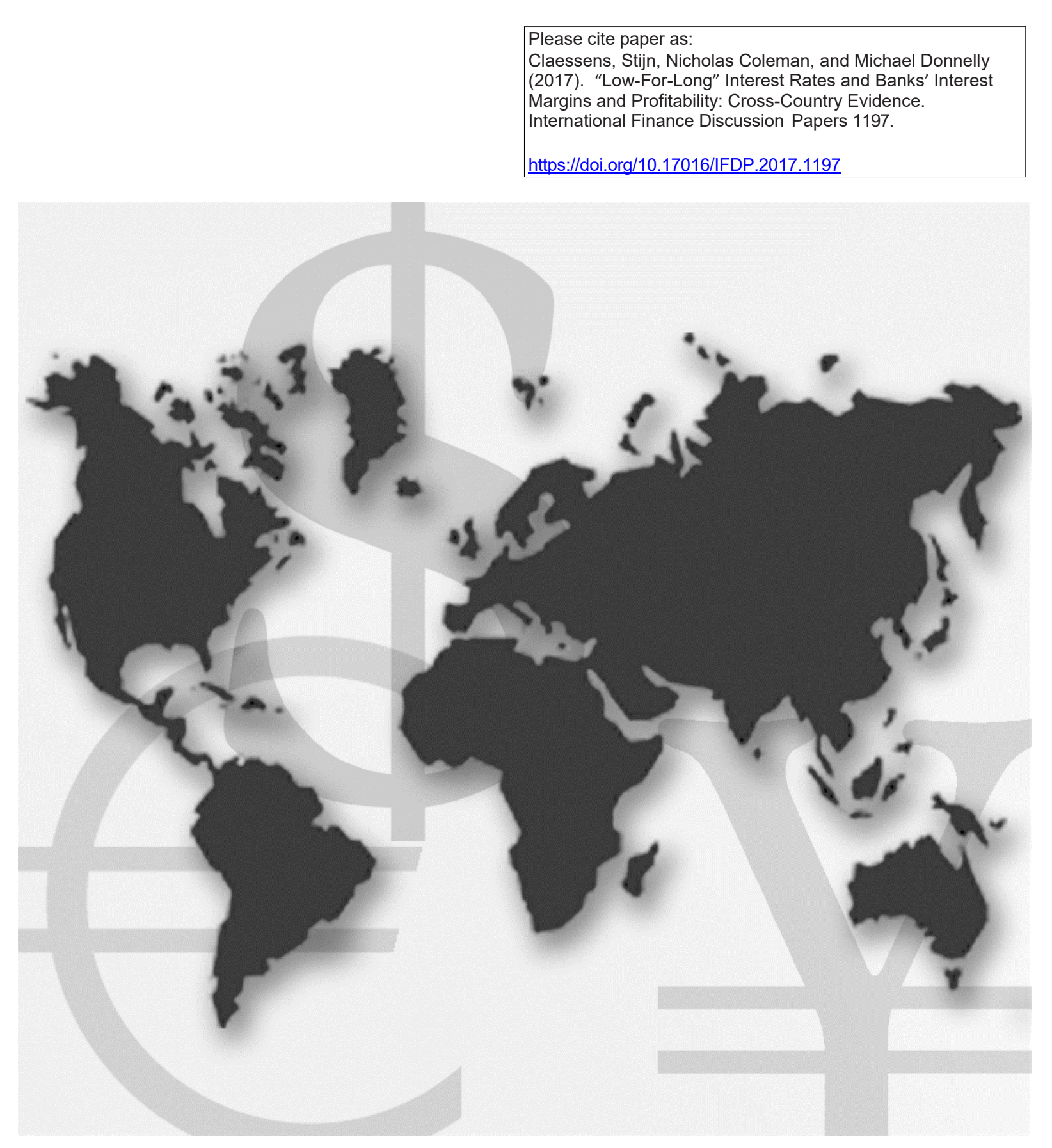

\section{International Finance Discussion Papers}

Board of Governors of the Federal Reserve System

Number 1197

February 2017 
Board of Governors of the Federal Reserve System

International Finance Discussion Papers

Number 1197

February 2017

\section{“Low-For-Long" Interest Rates and Banks' Interest Margins and Profitability: Cross- Country Evidence}

Stijn Claessens, Nicholas Coleman, and Michael Donnelly

NOTE: International Finance Discussion Papers are preliminary materials circulated to stimulate discussion and critical comment. References to International Finance Discussion Papers (other than an acknowledgment that the writer has had access to unpublished material) should be cleared with the author or authors. Recent IFDPs are available on the Web at www.federalreserve.gov/pubs/ifdp/. This paper can be downloaded without charge from the Social Science Research Network electronic library at www.ssrn.com. 


\title{
“Low-For-Long" Interest Rates and Banks' Interest Margins and Profitability: Cross- Country Evidence
}

\author{
Stijn Claessens ${ }^{\mathrm{a}, \mathrm{b}, \mathrm{c}}$, Nicholas Coleman ${ }^{\mathrm{a}}$, and Michael Donnelly ${ }^{\mathrm{a}}$
}

\begin{abstract}
Interest rates in many advanced economies have been low for almost a decade now and are often expected to remain so. This creates challenges for banks. Using a sample of 3,385 banks from 47 countries from 2005 to 2013, we find that a one percentage point interest rate drop implies an 8 basis points lower net interest margin, with this effect greater (20 basis points) at low rates. Low rates also adversely affect bank profitability, but with more variation. And for each additional year of "low for long", margins and profitability fall by another 9 and 6 basis points, respectively.
\end{abstract}

Keywords: Interest rates, Bank profitability, Net interest margin, Low-for-long

JEL classifications: G21, E43

${ }^{*}$ a Federal Reserve Board; ${ }^{b}$ University of Amsterdam; ${ }^{c}$ C.E.P.R.. We would like to thank very much the anonymous referee, participants in the IMF-FRB workshop on "Economic and financial stability implications of low interest rates," and various Federal Reserve System colleagues for extensive comments. The views in this paper are solely the responsibility of the author(s) and should not be interpreted as reflecting the views of the Board of Governors of the Federal Reserve System or of any other person associated with the Federal Reserve System. 


\section{Introduction}

Interest rates in many advanced economies have been low for almost a decade, since the global financial crisis (GFC), and in many cases are expected to remain low for considerably longer. Low interest rates can help economies recover and enhance banks' balance sheets and performance by leading to capital gains, supporting asset prices and reducing non-performing loans. But persistently low interest rates - "low for long" - may also erode the profitability and franchise value of banks, because low rates are typically associated with lower net interest margins (NIMs). Banks will often be reluctant to (quickly) lower deposit rates as interest rates decline, especially for retail depositors. On the other hand, banks must often still pass the lower rates on to existing and new loans based on contractual repricing and competition induced by borrowers who have other financing choices. As a result, when interest rates decline, passthrough of policy rates to various market rates may be imperfect, which could impede monetary policy transmission. And as bank margins tend to compress, this, in turn, may adversely affect banks' ability to lend as it erodes their capital positions. Both of these implications represent potentially adverse economic consequences and financial stability risks.

Some advanced economies' central banks are indeed facing challenges in monetary policy transmission and some of their banks are facing profitability challenges in part related to low rates and consequently lower NIMs. While bank profitability, measured by return on assets (ROA), in some advanced economies has recovered from the worst of the GFC, many advanced economies' banks have reported relatively weak profitability in recent years. Concurrently, banks in many countries with low rates have low market valuations, often with price-to-book ratios very much below one. While differences in profitability and valuations also reflect structural differences in balance sheet compositions, these declines in profitability and market valuation are in the eyes of some observers in part related to the lower interest rates. But how strong is the link between interest rates, NIMs, and profitability? And is this relationship different in low interest rate environments, i.e., are very low rates worse for margins and profitability? To date, answers to these questions are largely elusive.

This paper investigates the relationship between changes in interest rates, NIMs, and profitability for a large sample of banks in a wide spectrum of countries over a long period. Our large cross-country and relatively long panel allows us to analyze banks operating across various countries and in different interest rate environments in the same country, important for the identification of a differential effect when interest rates are low, while controlling for bank specific characteristics. The cross-country and time-series panel also provides us with a strong 
way to isolate the effect of a low(-for-long) interest rate through the erosion of banks' NIMs and profitability from other concurrent factors, such as overall competition in the respective banking system or other economic and financial developments. To our knowledge, the literature has not investigated this issue much and no other paper has attempted to answer this question with a time-series panel of banks for a large sample of countries.

Overall, our new empirical analysis shows that a low level of interest rates matters for NIMs in three ways: (1) declines in rates contribute to lower NIMs, as interest expenses fall less than interest income; (2) there is an adverse effect that is materially larger when interest rates are low, as they are currently in many advanced economies; and (3) the longer the rates are low, the more adversely NIMs are affected. We also find that there is a materially larger adverse effect from a falling spread between long- and short-term interest rates on profitability when rates are low. And profitability is more adversely affected the longer interest rates are low. These results hold controlling for general economic conditions and bank-specific balance sheet variables, including using bank fixed-effects. Additionally, results are robust to various econometric robustness tests, such as excluding outliers and dropping countries, and specifying different cutoffs for what constitutes a "low" interest rate environment.

While this paper identifies an adverse effect of low interest rates on banks' NIMs and profitability, the analysis does not provide an overall assessment of how low interest rates may affect banking systems. Besides leading to valuation gains on securities held by banks and other financial benefits, much of the overall effects will depend on the effects of low interest rates on the aggregate economy. If low (for long) interest rates stimulate the economy and thereby improve the quality of loans and the environment for lending and provision of other financial services, low interest rates could through such and other channels lead to an increase in a bank's overall capitalization, longer-term profitability and franchise value.

At the same time, besides the negative effects of low interest rates on banks' margins and profitability, there can be adverse effects on bank risk taking. While this paper does not address whether low interest rates lead to unhealthy reach for yield by banks, this has been a concern among many supervisors and policy makers, and has been a subject of research (see Adrian and Liang, 2014, and Dell'Ariccia and Marquez, 2013, for literature reviews of the links between interest rates and risk taking). The negative consequences of low (for long) rates on bank profitability and capitalization are additionally important to consider as analysis has suggested that the incentives for (excessive) risk-taking depend not just on the level of interest rate but also on the capitalization and franchise value of the bank (Dell'Ariccia, Laeven and Marquez, 2014). 
By adversely affecting over time the capital position of banks, low rates could furthermore adversely affect banks' willingness to lend. And a limited pass-through of policy rates, combined with the adverse effects on banks of low rates, could hamper monetary policy transmission and disrupt the transmission channel of interest rates to lending (the bank lending channel, e.g., Kashyap and Stein, 1995, 2000). More generally, low interest rates may adversely affect banks in a number of ways (see further Shin, 2016 for a discussion, and the model of Brunnermeier and Koby, 2016, with specific reference to negative interest rates; and the model of Begenau, 2015, with reference to the demand for safe assets). While this paper does not review these channels, the adverse effects we find of low interest rates for banks point to these possibilities.

The remainder of this paper proceeds as follows: Section II motivates the paper and reviews the literature on the effects of low interest rates on banks' NIMs and profitability, section III outlines our data and sample, section IV discusses our empirical framework and results, as well as some robustness tests, and section $\mathrm{V}$ concludes.

\section{Motivation and Related literature}

\section{Motivation}

How changes in interest rates affect banks' performance has been a subject of much practical and some academic research. Obviously, bank shareholders and other investors are keenly interested in how changes in interest rates affect the income and profitability of banks (e.g., see banking and investment textbooks such as Mishkin, 2015). Clearly effects will vary by bank, depending on their interest rate exposures, in turn a function of their degree of maturity transformation and use of risk management techniques, including derivatives (e.g., following the seminal contribution of Ho and Saunders, 1981). Relatively little focus has been given to the question of how low interest rates impact banks' NIMs and profitability differentially. Analytics (and most existing empirical findings, further reviewed below) suggest, however, that, controlling for other factors, banks' NIMs are lower when interest rates are low. The reasons typically mentioned are as follows.

Low short-term interest rates can depress bank margins, because for many types of deposits and some other liabilities, banks are reluctant to lower rates. In part, this is because of an effective lower bound, as depositors and other creditors can switch to cash-forms of savings. Banks may also fear losing clientele when they lower rates too much, clientele which are important to the banks' business in other ways than just funding. There is evidence, for example, 
that banks derive value from cross-selling products like consumer credit and mortgage to their depositors (e.g., Berger, Hancock and Humphrey, 1993; see further Mester, 2008). Indeed, the franchise value derived from a deposit is high enough to justify banks paying for acquiring a deposit, with premiums for core deposits historically of 1 to 2 percent. Both the lower bound and reluctance to lose clients reasons are especially large when interest rates fall below zero, as has recently happened in Japan and several European countries. While there is anecdotal evidence that some banks are passing negative rates onto corporate customers in select cases, banks have been reluctant to pass negative policy rates on to retail depositors (e.g., Bech and Malkohozov, 2016).

With deposit rates facing a floor, as interest rates decline, bank margins will compress if banks must still pass on lower rates on the asset-side of their balance sheet. The latter is likely to happen based on contractual repricing terms, e.g., on floating rate loans, or because there is an incentive to do so for those borrowers that have other financing choices, e.g., from corporate bond markets or other banks. ${ }^{1}$ Apart from the de-facto zero-lower-bound effects on deposit rates, effects of interest rates on NIMs are furthermore likely to be larger in a low-yield environment if, ceteris paribus, the spreads on loans over deposit rates increase with the level of the rate. This can be expected when spreads compensate for default and other risks that are otherwise interestinsensitive. More generally, as Appendix I models more formally, it is likely that the relationship between NIMs and interest rate is non-linear. As such, it is important to study separately the effects of changes in interest rate in general from those changes when the interest rate is low. While we focus less attention on the slope of the yield curve in this paper, because banks transform short-dated liabilities into longer-dated assets, their NIMs are likely also negatively affected by shallower yield curves, as has again been the case in many advanced economies in recent years. We therefore include the slope as well in our empirical analysis.

The effects of low interest rates on bank profitability are less obvious, even if NIMs were to decline. In many ways, banks benefit at least in the short-run from low interest rates. Directly, banks benefit through valuation gains on any fixed-income securities they hold, and, indirectly,

\footnotetext{
${ }^{1}$ The degree and speed of pass through will in part vary in line with maturities of existing assets and liabilities, which are mainly determined by contractual reasons. Banks will also vary their borrowing and lending contracts of course in response to changes in interest rates considering competitive conditions. For example, Cohen, Lee, and Stebunovs (2016) show that relationship between monetary policy rates and borrowing costs has become more tenuous in the markets for syndicated corporate term loans during the period of low interest rate than in the past, in particular in the United States, due to the use of floors by banks in response to desire from non-bank lenders for income protection.
} 
banks can additionally gain as non-performing loans diminish as borrowers' debt service becomes less burdensome. Lower interest rates may also spur the economy, and then, over time, increase profitability from new lending and the provision of other financial services. Whether these benefits offset the lower NIMs and increase profitability, and over which horizon they continue to do so, is not obvious, however. The valuation gains from lower interest rates, for example, do not continue if rates do not decline further. And the benefits from lower nonperforming loans depend on whether and to what degree low interest rates are associated with sustainable economic improvements and better firm and household prospects. This discussion does indicate that there can be lags in the effect of interest rate on NIMs and profitability. As such, it is important to use a longer time-series of data on banks, allow for lags, and study the time patterns over which the effects of interest rate changes manifest themselves.

This is the more so since over time banks can offset the impact of lower NIMs on profitability through cutting costs, and increasing non-interest income and raising the volume of lending, including internationally. At least in the short-term, however, and surely in the aggregate, banks have limited ability to fully offset any impact of declining NIMs as the scope for expanding non-interest income for an individual bank and banking system overall quickly is limited. This limitation is particularly true in those countries that are more bank-based where non-interest income is typically low, as capital market activities contribute little to banks' income. Although in the face of lower interest rates many banks have increased fees, e.g., ATM or account management fees, to better cover costs, many, especially European banks, still have a low share of non-interest income in revenues compared to say Canadian and US banks, reflecting their less developed asset management and other fee-generating financial services. This low share of non-interest income suggests limited scope for many banks to quickly increase other income streams. Since generating non-interest income may be particularly difficult for smaller banks which typically have higher shares of interest income, low interest rates may affect countries with many small banks, e.g. Germany and Italy, to a greater degree. This discussion, besides highlighting the time patterns in changes in profitability, also means that using evidence of banks from a cross-section of countries can help in identifying the effects of changes in interest rates on NIMs and profitability.

Lastly, it is important to acknowledge the endogeneity of monetary policy when considering the possible effects of changes in interest rates on banks. Central banks raise rates when the economy is doing well and lower them when the economy is doing badly. Economic 
conditions also directly affect a bank's ability to make loans and collect deposits. If economic conditions worsen, for example, loan demand is likely less, possibly lowering margins. Worse economic conditions could also lower household demand for savings, at least for financially constrained households. At the same time, spreads charged on lending could increase in times of weak demand if risks increase, raising margins. It is also possible that household saving goes up in more uncertain times, increasing the supply of deposits, thus also helping raise bank margins. While the net consequences of the various relationships among economic conditions, interest rates and banks' NIMs are thus not fully clear, overall, also being a margin, NIMs are less likely a function of economic performance and more likely a function of financial and monetary conditions. Profitability could be more likely adversely affected as weak economic conditions both lower demand for loans and other financial services and increase the need for loan-loss provisioning against possible defaults. As such, we could expect a less close relationship between interest rate and profitability. Regardless, it is important to acknowledge here both the endogeneity of monetary policy and that economic conditions have direct effects on banks. As such, we have to interpret any relationships we find between interest rates on one hand and NIMs and profitability on the other hand as not necessarily causal and more as benchmarks for further work.

\section{Related Literature}

Empirical evidence on the effects of the level of interest rates on bank performance is relatively limited, somewhat surprisingly. While there is a large literature on the effects of changes in interest rates on banks' performance and valuation, considering also the degree to which banks engage in maturity transformation and interest rate risk hedging, fewer papers have focused on how these effects on banks vary by the level of the interest rate. We divide the relevant literature into cross-country analyses, and country specific studies, with the latter analyzing also more the role of bank-specific characteristics.

One of the earliest cross-country studies using bank specific data on bank margins is Demirgüç-Kunt and Huizinga (1999). They investigate how a variety of macroeconomic and 
bank variables affect banks' net interest income and profitability. ${ }^{2}$ They find that higher interest rates are associated with higher net interest margins and profits, especially in developing countries, in part as there interest rates on deposits are more likely controlled and below marketrates. In a study specifically investigating the effects of interest rates on bank net interest margins, using aggregate data for 10 industrial countries over 20 years, English (2002) finds for many countries no evidence that changes in the levels of short-term and long-term rates or the slope of the yield curve influence contemporaneous bank net interest margins. These results would be consistent with banks using derivatives and other ALM-techniques to reduce interest rate risks, making banking systems relatively successful in minimizing the exposure of NIMs to changes in interest rates. He does find, however, in the case of the United States that the slope of the yield curve affects NIMs significantly and with the positive sign that the conventional view would suggest.

Even fewer studies have specifically investigated whether there is a difference in the effects of interest rate changes on banks' NIMs and profitability when interest rates are low. Using recent data and analyzing a sample of 108 relatively large international banks, many from Europe and Japan, and 16 from the United States, Borio, Gambacorta and Hofmann (2015) find non-linear relationships between the interest rate level and the slope of the yield curve and bank NIMs and profitability, i.e., ROA. They find that the effects on NIMs are much stronger at lower levels of interest rates (50 basis points for a 1 percentage point change at a rate of 1 percent vs. 20 basis points at a rate of 6 percent) and where there is an unusually flat term structure.

Analyses for various individual countries support the greater negative effects of low interest rates on NIMs. Genay and Podjasek (2014) finds that U.S. banks are adversely affected by low interest rates for an extended period of time through a narrower spread. They also note, however, that the direct effects of low rates are small relative to the economic benefits, including through better support for asset quality. Similarly, while not explicitly studying the effects of interest rates on banks, a study of $98 \mathrm{EU}$ banks (ECB, 2015) finds that macroeconomic factors, and not interest rates, have had the most importance for bank health since the GFC Analysis for Germany suggests that in "normal" interest rate environments, the long-run effect of a 100 basis points change on NIMs is very small at around 7 basis points (Busch and Memmel, 2015). This analysis was not conducted in a specifically low interest rate environment; however, the

\footnotetext{
${ }^{2}$ See also Barth, Nolle, and Rice (1997) who use bank-level accounting data for 1993 to study the impact of bank powers on the return to equity for a set of 19 countries.
} 
Bundesbank Financial Stability Review of September 2015, analyzing 1,500 banks, does find that persistent low interest rates weigh on German banks' profitability.

Evidence for other countries on the effects of (low) interest rates on NIMs and profitability is scarcer. Analysis using Japanese bank data shows that low-for-long interest rates also contributed to the declining NIMs of Japanese banks (Deutsche Bank, 2013). Over time, however, portfolio shifts towards investment in securities, a greater reliance on non-interest income, and a holding down of costs allowed Japanese banks' profitability to remain mostly positive. Furthermore, following a nearly two-decade experience with low-for-long interest rates, Japanese banks have started to expand internationally in recent years, possibly increasing profitability.

The literature has found that the direct effects of changes in interest rates on margins and profitability can vary by bank. Analysis for U.S. banks suggests that rate changes in general have a greater short-run impact on small banks as they depend more on traditional intermediation of retail deposits, which are stickier in price, into loans, many of which are priced off floating (prime) rates (e.g., Genay and Podjasek, 2014). While large U.S. banks typically have a greater ability to manage interest rate risks and reprice their liabilities, and would thus be less affected by low interest rates, they have since the GFC seen their funding cost advantage erode and NIMs decline more than small banks have. This seems, however, at least in part due to regulatory changes (Covas, Rezende and Voitech, 2015).

The differences between small and large banks in terms of the impacts of interest rate changes on net interest margin and profitability arise in part from differences in the compositions of their asset and liabilities, in the competition for funds and lending opportunities, and in general business models. Consistent with other evidence, Landier, Sraer and Thesmar (2013) show that in cash-flow terms, US banks are positively exposed to interest rate risks as their assets are more sensitive than their liabilities are, a risk which is typically not fully offset by banks' use of derivatives. This sensitivity varies across banks, however, and in turn leads banks' lending to respond differently to interest rate changes as their financing is affected differently (e.g., banks with greater exposure are more adversely affected by an interest rate decline). Variations in exposure to changes in interest rates across banks arise in part from differences in competition in deposit and loan markets. As shown by Drechsler, Savov, and Schnabl (2014), interest rates on deposits change less with changes in the Fed funds rate in markets where there is less deposit competition. 
Interest rate exposures also explain why stock returns of banks react to changes in interest rates (Flannery and James, 1984). ${ }^{3}$ Again, banks vary in their stock price exposures to changes in the interest rate in ways similar to how NIMs and ROAs exposures vary across banks. English, Van den Heuvel, and Zakrajsek (2012) find that while equity prices of U.S. banks typically fall following unanticipated increases in interest rates or a steepening of the yield curve, a large maturity gap weakens this effect, suggesting that on account of their maturity transformation function, banks lose relative to a lower interest rate or a shallower yield curve. Some large banks, with their greater international reach, have more potential to increase lending abroad, and their more diversified business models can allow them to more easily expand non-interest income to offset lower margins. At the same time, as documented by Calomiris and Nissim (2014), banks have seen many large changes in the values of their various business growth opportunities since the GFC and as rates have declined. A permanent reduction in interest rates reduces for example the gross value of core deposits, and given that branches still have non-interest expenses, maintaining deposit relationships could become a negative present value business. Their evidence using US bank data is consistent with lower interest rates reducing the market-to-book value of equity significantly. ${ }^{4}$ Our new cross-country analysis confirms and expands on these findings.

\section{Data and Sample}

To study the impact of interest rates on banks' NIMs and profitability we assemble a unique dataset from several sources. Table 1 provides a full list of variables used in our analysis and their sources. We first collect bank balance sheet and income statement data from Bankscope at an annual frequency. Where available, we use unconsolidated banking data to isolate the effect of a country's interest rate on only the bank's operations in that country. Our final sample

\footnotetext{
${ }^{3}$ In addition, banks are exposed to the shape of the yield curve. In a recent analysis, Begenau, Piazzesi and Schneider (2015) show that due to maturity transformation - borrowing short term and lending long term - an upward shift in the level of the yield curve in aggregate adversely affects the valuation of the US banking system.

${ }^{4}$ Ritz and Walther (2015) develop a model where funding uncertainty can explain: (i) lower lending volumes and profitability; (ii) more intense competition for retail deposits; (iii) stronger lending cuts by more highly extended banks with smaller deposit bases; (iv) weaker pass-through of interest rate changes; and (v) a binding "'zero lower bound."
} 
contains 3,385 banks from 47 countries for 2005-2013. ${ }^{5}$ We provide a full set of summary statistics in Table 2, Panel A. In the base regressions, we trim observations in cases where the data is logically inconsistent (for example, when assets are below zero or when deposits are greater than liabilities). We additionally trim outliers that are more than five standard deviations from the mean and censor observations where the NIM or ROA for a bank changes by more than ten percentage points from one year to the next. ${ }^{6}$

The bank level income variables NIM, and ROA show considerable variations, even after these trimmings. While the standard deviation of NIMs is higher than that of ROA, 1.91 vs. 1.06, relative to their means, 2.76 and 0.52 respectively, there is more variability in the ROAs. This may not surprise as year-to-year overall income, capturing the overall effect of various factors and decisions by bank management, is likely to vary considerably. While interest expenses margins also have a higher standard deviation than interest income margins, relative to their means, interest expenses margins are less variable than interest income margins. Deposit over liabilities ratios vary considerably across observations, with a low of 4 percent and a high of 100 percent, a reflection of the fact that our data includes both banks involved in traditional financial intermediation, with higher deposit to liabilities ratios, as well as those that are more engaged in capital market transactions which may also fund themselves more in whole-sale markets. Banks' capitalization varies as well. Furthermore, the relative importance of bank- vs. market-based financing varies greatly across our sample of countries, which explains in part the variation in the securities over assets ratio across banks, varying between 0 and 97 percent.

We next calculate yearly averages of the three-month and ten-year implied sovereign yields from Bloomberg by country and calculate the spread (slope of the yield curve) between the ten-year and three-month rates. $^{7}$ To explore whether there is a differential impact of changes

\footnotetext{
${ }^{5}$ Bankscope oversamples large banks within countries, but many smaller (and unlisted) banks are still included in our sample. We exclude the US as it would dominate the sample in terms of number of banks. Regression results are robust, however, to including it.

${ }^{6}$ Accounting differences across countries can limit direct comparability of financial reports. For example, derivatives are reported at net value for U.S. banks but at gross value under International Financial Reporting Standards, which has the effect of inflating assets and reducing return on asset figures for many other economies' banks. Gross derivatives represent roughly 15 percent of European bank sample assets on a weighted basis, for example, a material share, but not one that would substantially affect these comparisons. Furthermore, since all regressions include bank fixed effects, results are not likely affected by these accounting differences.

${ }^{7}$ Implied yields on currently outstanding three-month and ten-year bonds are used because not every country has bonds maturing exactly three months or ten years later. These daily rates are then averaged over each year.
} 
in interest rates on bank NIMs, a country is classified each year as being in a low- or high-rate environment based on whether the interest rate on its three-month sovereign bond is below or above 1.25 percent. We test for other cutoffs as well and the results are broadly consistent. As seen in the bottom part of Table 2, Panel A, the average (median) three-month and ten-year sovereign yields are $1.94(0.76)$ and 1.65 (1.43), respectively. There is significant variation in interest rates across countries. The wide variation can also be seen in Figure 1 which shows the range and median of the short-term yields for each country. Importantly, the within-country variation in rates is large, and many countries are both in the high- and low-yield environment at some point in our panel. Figure 2 shows the exact classification of countries in the low- and high-yield environments for 2005, 2009, and 2013. It is notable that many more countries, especially advanced economies, are in the low-yield environment post-GFC: 19 in 2009 versus only two in 2005. These shifts help to estimate the differential impact of low interest rates on banks' NIM and profitability.

Table 2 Panel B shows the average NIMs and ROAs for the different sample of bankyear observations in the high-rate environment and the low-rate environment. The panel shows only data for those banks in the 22 countries that experienced both the high-rate environment and the low-rate environment (as also depicted in Figure 1), which also explains why the number of bank-level observations in the two samples are roughly equal. Here we clearly find that NIMs and ROAs are higher in the high-rate environment than in the low-rate environment, with differences for both NIMs and ROAs statistically significant between the two samples. The table also shows that there are statistically significant differences in the interest income to asset ratio and the interest expenses to liabilities ratio between the high and low interest rate environments. Consistent with the lower NIMs in the low interest rate environments, the gap between interest income and interest expense margins is smaller in the low interest rate environment (224 basis points) than in the high interest rate environment (238 basis points). ${ }^{8}$ Profitability is about 14 basis points higher in the high-rate environment, likely reflecting the higher NIMs, but possibly also concurrent better overall economic and financial environments. Data (not shown) also reveal that NIMs are somewhat higher for small banks than for large banks, possibly reflecting different business models for large banks, but profitability is roughly equal for large and small banks. Besides the (expected) statistically significant differences in the level of the interest rate, there is

\footnotetext{
${ }^{8}$ As these interest income and expense margins are calculated using as denominators different subsets of overall assets and liabilities, the difference between the two interest margins is not exactly equal to the NIM.
} 
also a statistically significant difference in GDP-growth rates between the two regimes, making it thus important to control for economic conditions.

Lastly, Panel C provides the correlations between the key variables for the different samples. For the full sample of bank-year observations, the correlation between the level of the interest rate and NIMs is high, 0.54, and between the interest rate and ROAs somewhat lower, 0.36. The correlations between the level of the interest rate and interest expense and income margins are even higher, at 0.72 and 0.69 respectively. The corresponding correlations between the interest rate slope of the yield curve and our outcome variable are much lower, especially for ROAs, likely because other factors confound the impact of interest rate changes. The correlations between the three balance sheet variables and the interest rate level and slope, although not very high, point towards the need to consider these bank conditions. In the next section, we formally control for these and other factors.

\section{Methodology and findings.}

To isolate the direct effects of changes in interest rates on NIMs in low- and high-rate environments, we perform an econometric analysis that holds other factors constant, including any correlations that interest rates might have with economic growth, demand for loans, or supply of deposits. We regress a bank's NIM in each year on the level of the three-month sovereign rate, a common proxy for banks' marginal funding costs, and the spread between the three-month and ten-year sovereign rates, controlling for the bank's own lagged NIM, other time-varying bank characteristics, as well as the country's GDP growth in the year, and including a bank fixed effect and a time (year) fixed effect. The regressions are split by observations of bank-years in low- vs. high-rate environments. Specifically, the base regressions use the following empirical specification:

$$
\begin{gathered}
y_{i j t}=\beta_{0}+\beta_{1} y_{i j t-1}+\theta_{1} \text { 3MonthRat }_{j t} \\
\quad+\theta_{2} \text { RateSpread }_{j t}+\theta_{3} \text { Low }_{j t}+\theta_{4} \text { 3MonthRateXLow }_{j t}+\theta_{5} \text { RateSpreadXLow }_{j t}+\gamma_{1} \text { GDPgrowt }_{j t} \\
\quad+\gamma_{2} X_{i t}+\delta_{i}+\zeta_{t}+\varepsilon_{i j t}
\end{gathered}
$$

Where:

- $y_{i j t}$ is the NIM (or ROA) of bank $i$ in country $j$ in year $t$,

- 3 MonthRate $_{j t}$ is the yearly average 3-month government bond yield,

- RateSpread - $_{j t}$ is the spread between the 10-year government bond yield and 3-month government bond yield, 
- Low $_{j t}$ is a dummy equal to 1 if the country $j$ in a specific year $t$ is in a "low rate environment" which we define in the base specification if the 3-month rate is under 1.25 percent,

- GDPgrowth ${ }_{j t}$ controls for the country's economic growth,

- $X_{i t}$ are bank level controls, specifically deposits over total liabilities, total equity capital over total assets, and total securities over total assets, and

- $\delta_{\mathrm{i}}$ is a bank fixed effect, $\zeta_{\mathrm{t}}$ is a time (year) dummy, and $\varepsilon_{\mathrm{ijt}}$ is an error term.

Because the regressions control, through the various bank variables and the bank fixed effects, for each bank's average NIM (or ROA), results can be interpreted as the direct effects of a change in the short-term interest rate and in the slope of the yield curve on banks' NIMs (or ROAs). Since the regressions include the countries' GDP growth rates and general time fixed effects, they also control for general economic conditions, acknowledging the difficulty to fully address the endogeneity in monetary policy. Note that the general time fixed effects control as well for any commonality across countries. For example, since many of the advanced countries in our sample suffered from the GFC and lowered interest rates at the same time, it could be that results are driven by the joint impact of the crisis and policy makers' attempts to contain the crisis (through reducing interest rates). The time dummies also control for any common regulatory changes that may have affected banks' performance.

Table 3 reports the baseline regression results for the NIM as the dependent variable, using first as a sample all banks and then splitting the sample between those bank-year observations in the low- and those in the high-interest rate environments. All regressions are clustered at the country level. ${ }^{9}$ The regression result in column 1 shows that NIMs are positively related to the level of the short-term interest rate, with a coefficient of about 0.09 in the sample of all bank-year observations. This result implies that a decrease in the short-term interest rate of one percentage points lowers NIMs by about 9 basis points (with effects symmetric for an interest rate increase). We next study banks operating in a low- vs. high-rate rate environment in columns 2 and 3. We find that, other things equal, the negative effects of a lower interest rate are larger in a low rate environment than in a high interest rate environment as the coefficients are 0.198 vs. 0.0761 , with this difference statistically significant (at the 10 percent level). This means that for a representative bank, a one percentage-point decrease in the short-term rate is

\footnotetext{
${ }^{9}$ We also clustered at the bank level and found all regression results to be confirmed.
} 
associated with an 8 basis-point decrease in NIM in the high rate environment versus a 20 basispoint decrease in NIM in the low-rate environment, a 12 basis points difference.

We also find positive effects on NIMs related to the slope of the yield curve, which is to be expected since a large role of banks is maturity transformation. These effects statistically differ between low- and high-rate rate environments, as banks have a statistically significant higher sensitivity to the spread variable in the low interest rate environment, 0.134 , compared to an insignificant 0.005 in the high rate environment. This means that for every one percentage point change in the slope, the NIMs vary by about 13 basis points in the low interest rate environment. While we will continue to include the slope in the regressions, we will focus less on the results on the slope for this paper.

In terms of other variables, we find, as expected, a positive coefficient (of about one-third for the full sample) on the lagged dependent variable, indicating that NIMs adjust over time. Note that the coefficient on the lagged dependent variable is much lower in the low interest rate environment, suggesting a different adjustment process. Banks that rely more on deposits do not have statistically significant different NIMs, as the zero coefficient on the deposit over liabilities variable shows, with no differences by interest rate environments. Better capitalized banks have typically higher NIMs, but, as the smaller coefficient for low environment suggests, see less of a positive impact of capitalization on NIMs in a low interest rate environment. In terms of asset composition, those banks that have higher securities to assets ratios, i.e., are less engaged in lending, have in general lower NIMs, possibly reflecting lower-yielding securitized mortgages and sovereign debt, with this effect stronger in high interest rate environments. Finally, the coefficient on GDP growth is insignificant in the low and significantly negative in the high interest rate environment. While not consistently significant, the negative sign nevertheless does not support an interpretation that NIMs are high (low) in high (low) interest rate environments because of concurrent strong (weak) economic activity and related lending opportunities.

We next run the same set of regressions, but now including time fixed effects. Results are shown in columns 4-6 of Table 3. We find that the regression results are affected, in that the effect of interest rates on NIMs is smaller, a coefficient of 0.04 , and is no longer larger in a low interest rate environment (statistically, the coefficients are not significantly different). Other regression results though are largely confirmed. As such, it suggests that the earlier regressions may be capturing in part a common time trend across all countries, possibly due to advanced countries in the sample all lowering their interest rate after the GFC or the greater regulation and 
more intense supervision that followed the crisis. While these results thus do not imply we have to reject the main hypothesis, we do have to caveat it.

Using the same base regression (in columns 1-3), samples composed of different banks and countries were also used as robust tests (not reported). Specifically, similar levels of significance and direction of coefficients are found when using unbalanced or balanced samples, samples with or without U.S. banks, and trimming observations differently. Even though, when conducting the analysis for individual countries, we find qualitatively the same results, there is significant quantitative heterogeneity in effects.

We next decompose the dependent variable NIM and consider separately the interest income margin, i.e., interest income to earning assets ratio, and the expense margin, i.e., interest expenses to interest-bearing liabilities ratio, first for all bank-year observations, and then for those separately in the low and high interest rate environments (note the NIM is not exactly the equal of the difference since the two ratios use slightly different denominators). This analysis allows us to identify more precisely the mechanism by which NIMs adjust in response to interest rates: specifically, do assets reprice differently than liabilities? We use otherwise the same specifications as in Table 3. Regression results are reported in Table 4.

We find that the effects of interest rates are generally larger on the interest income margin (columns 1-3) than they are on the interest expense margin (columns 4-6), suggesting that banks have to reprice their assets more aggressively than their liabilities. While for the full sample the difference in coefficients is only 6 basis points $(0.362$ vs. 0.303$)$, there is a much greater adverse effect of interest rate changes on NIMs in the low-rate environment on interest income than on interest expense, which appear to largely drive the greater pass-through of low interest rates. Specifically, a one percentage point decrease in the short-term rate is associated with a 67 basis-point decrease in the ratio of interest income to earning assets in the low-rate environment (column 2) and only a 30 basis-point decrease in the high-rate environment (column 3), a 37 basis-point difference. The equivalent difference is about 26 basis points for the ratio of interest expense to liabilities, 51 basis points (column 5) - 25 basis points (column 6), i.e., 11 basis points less than for the interest income margin. In other words, at low rates, banks have to pass on more of the lower interest rate to both their borrowers and lenders, but have greater difficulty reducing their funding rates, while they still have to pass the lower rates to a significant degree on to their borrowers, likely due to greater competition, including from non-bank lenders, leading NIMs to decline more. Equivalently, the differential in pass-through in a low interest rate 
environment on incomes vs. expenses of about 16 basis points (67 minus 51) can be compared to the 5 basis points $(30-25)$ differential effect in a high rate environment, which makes again for about 11 basis points difference on the NIMs. These regression results thus also confirm the general result of Table 3 that banks' NIMs are about 12 basis points more sensitive to the interest rates when it is low.

Table 5 provides regression results when we split the sample between small, columns 13, and large banks, columns 4-6, where columns 1 and 4 show the regression results for the full samples and the other columns show the split by low and high interest rate environment for respectively large and small banks. These results suggest that the effects of interest rates on NIMs are in general comparable for the two classes of banks, with the coefficients on the level and slope of the interest rate being somewhat large in magnitude for the small set of banks compared to the large banks (columns 1 vs. 4). The split by the level of interest rate furthermore shows that in a low environment the effects of changes in interest rates is relatively larger for small banks than it is for large banks. Specifically, the difference between the coefficients on the short-term interest rate in the low interest rate environment vs. the high interest rate environment is about 0.07 (0.153-0.0789) for large banks and $0.13(0.197-0.0699)$ for small banks. This implies that small banks have greater difficulty maintaining their NIMs in a low interest rate environment, possibly as they do not hedge interest rate risk or lack the means to attract other funding sources than deposits and thus cannot avoid having to keep their deposit rate high. Overall, it thus seems that the differences in the interest rate sensitivity of NIMs between small and large banks (columns 1 vs. 4) is largely driven by the higher sensitivity of small banks in the low interest rate environment.

The higher sensitivity to the slope variable in the low interest rate environment seems also driven by the small banks that have perhaps less ability to hedge such risks than large banks do. The lagged dependent variable has about the same coefficient for large banks in both environments, but is smaller for the small banks in the low interest rate environment, which may again reflect the challenges for these banks in maintaining their NIMs. The other control variables have generally the same signs and similar size coefficients for both groups of banks: better capitalized banks have higher NIMs as do banks with a lower ratio of securities on their balance sheets. Deposit funding is less relevant for both sets of banks and interest rate environments. And when the GDP growth rate is statistically significant, its sign remains negative. 
We next analyze if effects differ by banks' assets and liabilities' maturities and related mismatches. This analysis both allows us to confirm the mechanism by which NIMs adjust in response to interest rates, which relate to the (degree of) repricing of assets and liabilities, and assess if the nature of adjustment varies by duration. We define a bank as having a "long" maturity if it has an average balance sheet maturity (asset and liabilities separately) over the sample period greater than the median maturity for banks in its country and classify it as having a "short" maturity otherwise. We then analyze again the impact of a one percentage point change in the short-term interest rate on the same period interest income margin and the interest expense margin. ${ }^{10}$

Regression results are reported in Table 6, for the interest income margin in columns 1-6 and for the expense margin in columns 7-12, using the standard specifications (of Table 3). Consistent with a priori expectations, the regression analyses show that the highest contemporaneous pass-through of a change in interest rates to interest income is for those banks with short asset maturities and especially so in the low interest rate environment (column 3). Here the coefficient on the interest income margin is 0.936 , implying that a decrease (increase) in interest rate is almost fully passed on to interest income in the same year. The pass-through for the long asset maturity banks in the low interest rate environment is less, but still quite large, 0.66 (column 4). In contrast, in the high interest rate environment, the pass-through is much lower for both short and long asset maturity banks, 0.32 and 0.22 respectively (columns 5 and 6). The difference in coefficients between the high and low interest rate environment for banks with short asset maturity is more than 60 basis points and for banks with long asset maturity almost 45 basis points. Of these differences, the ones between columns 3 and 5 and between 4 and 6 are statistically significant, but the ones between columns 3 and 4 and between 5 and 6 are not.

Similar, although of somewhat lower magnitudes, are the coefficients for the passthrough to interest expense and the differences in these coefficients between the low interest rate environment and the high environment. Specifically, results show that banks with short maturity liabilities see higher pass-through than banks with long maturity liabilities, 77 basis points vs. 52

\footnotetext{
${ }^{10}$ Besides differences in maturity structure, there can also be differences in the frequency of repricing of claims with the same final maturity, as for example, in fixed vs. variable rate mortgages. Data on such differences is not available, however, consistently for our full sample of banks and countries. We can therefore only analyze, and even then only for a smaller sample of banks, when differentiating by the maturity of the banks' assets (liabilities). Separately, regressions using the base specification, not reported, confirm for this sample the results reported in Table 3, columns 1-3.
} 
basis points in the low rate environment (columns 9 and 10). Importantly, the coefficients for the banks with short liability maturities are higher in the low interest rate environment than in the high environment, 0.77 vs. 0.52 , a difference which is statistically significant. For the banks with long liability maturities, the coefficients are not (statistically significant) different from each other in the two interest rate environments, both are about 0.5 (columns 11 and 12). Together, this suggests that the greater pass-through of interest rates to NIMs in a low interest rate environment arises in large part from the fact that banks have to reprice their short-maturity assets quickly, likely also related to greater competition among lenders in the markets for shortterm financing, while they are limited in how much they can adjust their short- and long-maturity liabilities, possibly in part related to the effective lower bound on (retail) deposits and other liabilities.

In terms of the other bank balance sheet control variables, we find that once we start splitting the sample finer these variables in general lose some of their statistical significance. The deposit over liabilities ratio and equity over assets ratio seems important in explaining the interest expense margin, but signs or significance are not consistent across regressions. The securities over asset ratio matters for this margin rarely as well. What is consistent is the negative sign on the country's GDP growth for both margins, but with somewhat higher coefficients on the expense margin, suggesting that combinations of low interest rate and low growth make maintaining NIMs even more challenging.

\section{Regression results for $R O A$}

We next repeat the regressions we did for NIM in terms of bank profitability using ROA as the dependent variable. As noted, for a variety of reasons, we do not expect a relationship between interest rates and ROAs that is as clear or close as that between interest rates and NIMs. Table 7 provides the base regression result using similar specifications as in Table 3, where we split the sample into bank-year observations in the low- or high-interest rate environments, and also split by large vs. small banks, as well as reporting the regression results for the full respective samples. It shows that ROAs are a positive function of the level of the interest rate, but one that is not statistically significant for any of the samples. The effect is also small, on the order of 3 basis points change for a 1 percentage point change in the interest rate. The general effect (in column 1) is smaller though than that in low interest rate environment (column 2), and about the same as in the higher interest rate environment (column 3), but with the difference between the two interest rate environments not statistically significant (columns 2 vs. 3). As 
such, there is limited evidence that a lower interest rate adversely affects banks' profitability more. This difference is greater for large banks (columns 5 vs. 6), but for small banks there is little additional effect of being in a low interest rate environment (columns 8 vs. 9) as the size of the coefficients there are very similar. Overall, the effect of the level of interest rates is not strong, possibly as effects on profitability through the NIMs are offset by other items, such as gains on securities from changes in interest rates.

The relationship of ROA with the slope of the yield curve is statistically more often significant, and consistently larger in the low interest rate environment, i.e., there appears to be a differential effect from being in a low environment. Actually, the relationship is statistically significant negative in the high environment for all and large banks, and statistically significant positive for all and small banks in the low environment. The fact that the coefficient on the spread is negative in the high interest rate environment, and statistically significant for the entire sample of banks and large banks, could possibly reflect that a higher slope is generally associated with more adverse economic conditions (note that GDP growth is now consistently positive, indicating that channel as well). Overall, though the coefficients for the slope of the yield on ROAs differ in similar ways for the three samples between low and high environments, with the more adverse effects coming from the low interest rate environment and the three differences all statistically significant.

\section{Low-for-Long}

We next consider in more detail the time patterns by which banks' NIMs get adjusted to get some insights as to what happens when interest rates end up being low for some time. As documented for the United States, the adjustment of deposit rates takes about 3 weeks in the time series (Yankov, 2014), and about 1-2 weeks in the cross-section (Drechsler, Savov, and Schnabl, 2014). Given that our data is at the annual level, it is thus unlikely that slow adjustment of retail deposit rates would account for much of an adjustment effect on bank NIMs or profitability. Even when rapid, however, adjustments of borrowing and lending rates may be done

incompletely, i.e., not one-to-one, given the effective lower bound of (near) zero on deposit rates, the fear of losing customers which provide other valuable business, or other reasons, including competitive conditions. Also some liabilities and loans, even though having a longer-term maturity, have floating rates and are thus repriced quickly at higher or lower interest rates. But even when posted rates change quickly in response to changes in interest rates, the repricing of some other liabilities and assets, and the resulting effects on NIMs and profitability can take 
some more time. Many liabilities and assets (e.g., certificates of deposits, in many countries mortgages) have their interest rates fixed over the duration of their contract and changes in interest rates then only show up gradually in NIMs and profitability. There could be additional lags in the relationship between changes in interest rates and NIMs and profitability. Banks for example may avail themselves of (off-balance sheet) hedging activities which can mitigate the contemporaneous effects of a change in interest rates on interest income or expense margins or on profitability.

Data allowing for analyses of the roles of various individual channels are not easily available (hedging, for example, is not captured in Bankscope data, and competitive conditions in the various market segments are not easy to capture). Nevertheless, investigating the time patterns of how changes in interest rates show up in NIMs and profitability addresses the question which is being asked in policy circles on what the effects of "low for long" interest rates may be on financial institutions and monetary policy transmission, and in turn for financial stability and economic activity (see for example, Bean et al 2015). We investigate this question by explicitly considering the length of time, that is, the number of years, the bank has been in a low interest rate environment, using both the number of years and dummies for each (additional) year the country is a low interest rate environment. Since we no longer study the banks that have only been in a high or low interest rate environment, the sample of bank-year observations drops to about half.

Table 8 reports the regression results. Results in column 1 show that the overall effects of a change in interest rate of 1 percentage point are about 16 basis points, similar to what was reported in the base regression for banks in the low interest rate environment (Table 3, column 2), but now for a smaller sample. Column 2 shows that the adverse effect of a low interest rate on NIMs depends on the number of years the bank spends in the low environment as the coefficient on Years in Low is statistically significant and negative. The decline in NIMs is about 8 basis points for an additional year. We next investigate the time-pattern in the effects (column 3): we find that the largest adverse effects on NIMs come in the $3^{\text {rd }}$ and $4^{\text {th }}$ year, about 38 to 40 basis points. This is consistent with banks having assets and liabilities that reprice over 1 to 2 years and engaging in some hedging activities (note that in this specification the contemporaneous effect of a 1 percentage point lower interest rate on the NIM remains similar, 16 basis points, but is no longer statistically significant). These regression results confirm analysis using German banks, Memmel (2011), which suggests that the full effects of repricing take a period of 1-1.5 
years. Together, these results confirm the general concerns that there are some additional adverse effects on banks' NIMs from being long in a low environment.

Columns 4-6 of Table 8 report the regression results where we consider the effect of interest rates on profitability depending on the length of time the bank has been in a low interest rate environment, with the first column using the base regression specification, but finding less significant results for this smaller sample of banks. We find, similar to the results for the NIMs, that there are increasingly adverse effects on profitability the longer the bank is in a low environment (column 5), with effects to amount to about 6 basis points per year. Considering the time pattern (column 6), it appears that the adverse effects are some 15-20 basis points in the first two years and then increasing to some $25-30$ basis points in the $3^{\text {rd }}$ and $4^{\text {th }}$ year. Only in the last year, however, is this effect statistically significant. Overall we thus find that there are additional, economically important effects of low interest rates on profitability when rates are low for long. This also suggest that banks can only partially offset in the short- and even medium-term the effects of lower NIMs on profitability through generating non-interest forms of income or reducing their interest expenses.

\section{Country risks}

So far, we have used the 3-month and 10-year sovereign rates as the relevant rates in terms of affecting banks' NIMs and ROAs since banks' borrowing and lending rates are typically priced of the local sovereign rates. At the same time, sovereign rates can include some elements of country risks. While US Treasury and many other countries' bills and bonds can be considered riskless, this does not necessarily hold for all countries. For example, our sample includes countries that were heavily affected by the European sovereign crisis such as Greece, Portugal, Spain, and Italy, as well as politically unstable countries such as Venezuela. As such, the sovereign rates we use are not necessarily risk-free rates. To the extent, however, that banks' riskiness is correlated with sovereign risk (as many papers have shown, e.g., Acharya et al., 2015, sovereign risks are correlated with bank credit risk) and that banks' borrowing and lending rates are priced off local sovereign rates, we can still expect the NIMs and ROAs to be a function of the sovereign rates, including the risk premium in them. As such, the regressions are likely still well-specified.

Nevertheless, as a robustness exercise, we investigate if accounting for sovereign risks would alter our main results for the NIMs. We do so by including in the base regression for those 
countries where it is available to us, the sovereign CDS as a proxy for sovereign credit risk (the sample size is slightly reduced, from 27,216 to 23,472 bank-year observations). Table 9 reports the results, where columns 1, 3 and 5 repeat for the various samples the specifications as in Table 3, columns 1-3 (since the composition of banks is slightly different, results are not exactly the same). The sovereign CDS itself is negative for the full sample and for the bank-year observations in the low interest rate environment, where it especially helps to explain the lower NIMs. Comparing the regression results in columns 2, 4 and 6 with those in columns 1, 3 and 5, however, shows that adding the sovereign CDS does not alter the main findings. The general effect of a 1 percentage point change in interest rate on NIMs remains about 6 to 7 basis points (comparing column 1 with 2). And, even though the coefficient on the interest rate in the low interest rate environment declines somewhat when including the sovereign CDS, from 0.20 to 0.15 , suggesting that sovereign risk exerts some adverse effects on NIMs as well, the interest rate effects are again the largest for this sample. The regression results for the slope of the yield curve are similarly confirmed when including the sovereign CDS, with the largest effects again in the low interest rate environment.

\section{Conclusion}

This paper investigates the effects of (low) interest rates on bank net interest margins (NIMs) and profitability. We find that low interest rates have a significantly greater impact on bank NIMs than high interest rates. The impact is greater on interest income margins than on interest expense margins, and banks with short maturity balance sheets are more affected than those with long maturity balance sheets. Effects on banks' profitability are less strong, perhaps in part as low interest rates can provide for some valuation gains and as banks mitigate the impact from low rates on overall profitability, possibly through cost cutting and generating more noninterest income. Nevertheless, the fact that profitability is also negatively related to the length of time interest rate are low shows the challenge for banks to maintain their income if low interest rate environments persist, especially for more than a few years. While institutions can make adjustments to offset the low rates' adverse effects on profitability (as well as to offset, also in light of recent regulatory changes, heightened market pressures, and changed opportunities), such efforts take time and likely have limited immediate payoffs, especially when facing weak cyclical conditions and deleveraging pressures. Challenges to maintain income may be especially acute for those banks that already have low NIMs and high cost structures. 
The adverse effects of low interest rate on banks' NIMs and profitability raises some policy issues. One is the possible adverse effects on the transmission of monetary policy: as the low interest rate undermines banks' capitalization and ability to lend, it can impede the bank lending channel, and thus may make lowering interest rate a less effective tool to stimulate economic activity. ${ }^{11}$ Another important issue is what the effects of "low for long" interest rates are for banks' longer-term capitalization and franchise value. Until lost income from lower NIMs can be offset through other actions, lower profitability will reduce financial institutions' ability to build and attract capital, increasing their vulnerability to shocks and declines in market confidence, and undermining their ability to support the real economy. Both an impeded monetary policy transmission and a weaker banking system capitalization can adversely affect economic activity and financial stability going forward. As banking systems in many low interest rate countries already had relatively low NIMs, those especially will have to adjust their activities and cost structures so as to offset low rates' adverse effects on profitability and capital.

Our regression results do come with some caveats. First, some limits to the analysis relate to appropriate lags and potential non-linearities between changes in interest rates and NIMs. There may be lags, which also vary by banking system, as well as important non-linearities in the impact of interest rate changes in a low-yield environment compared to the high-yield environment not captured with our specification. Second, our analysis only looks at the effect on current margins but does not study any shifts in behavior. Changes in interest rates' effects on banks' NIMs (and profitability, capital adequacy and franchise values over time) may vary, however, as banks adjust their funding structures, lending and investment portfolios and their non-interest activities. These adjustments have been found to be important in the case of Japan. Also, there have been many regulatory changes since the GFC that could have affected banks' NIMs, which we only capture in a very aggregate way. Lastly, it is important to acknowledge the endogeneity of monetary policy to economic conditions, with the latter also having their own direct effects on banks' performance. As such, the relationships we find between interest rates on one hand and NIMs and profitability on the other hand as not necessarily causal.

\footnotetext{
${ }^{11}$ Gambacorta and Shin (2016) analyze this, and Brunnermeier and Koby (2016) and Drechsler, Savov and Schnabl (2016) provide models. See further Brunnermeier and Sannikov (2017) for modelling and Coeure (2016) for a discussion when rates are negative.
} 


\section{References}

Acharya, Viral, Itamar Drechsler, and Philipp Schnabl, 2015, A Pyrrhic Victory? Bank Bailouts and Sovereign Credit Risk, Journal of Finance, 69(6), 2689-2739.

Adrian, Tobias, and Nellie Liang, 2014, Monetary Policy, Financial Conditions, and Financial Stability, Federal Reserve Bank of New York Staff Reports, no. 690 September.

Barth, James R., Daniel E. Nolle, and Tara N. Rice, 1997, Commercial banking structure, regulation, and performance, an international comparison, Comptroller of the Currency Economics Working Paper 97-6.

Bean, Sir Charles, Christian Broda, Takatoshi Ito, Randall Kroszner, 2015, Low for Long? Causes and Consequences of Persistently Low Interest Rates, 23 October, 17th CEPR-ICMB Geneva Report on the World Economy, CEPR.

Bech, Morten Linnemann, and Aytek Malkhozov, 2016, How have central banks implemented negative policy rates?, BIS Quarterly Review, March, 31-44.

Begenau, Juliane, 2015, Capital Requirements, Risk Choice, and Liquidity Provision in a Business Cycle Model, Harvard Business School, Working Paper 15-072.

Begenau, J., M. Piazzesi, and M. Schneider, 2015. Banks’ risk exposures. NBER WP No. 21334.

Berger, A., D. Hancock, and D. Humphrey, 1993. Bank efficiency derived from the profit function. Journal of Banking and Finance 17 (2-3), 317-347.

Borio, Claudio E.V., Leonardo Gambacorta, and Boris Hofmann, 2015, The Influence of Monetary Policy on Bank Profitability, BIS Working Paper No. 514.

Brunnermeier, Markus K. and Y. Koby, 2016. The reversal interest rate: The effective lower bound of monetary policy. mimeo, Princeton University.

Brunnermeier, Markus K. and Yuliy Sannikov, 2017, Macro, Money and Finance: A Continuous Time Approach, Handbook of Macroeconomics, Volume 2, North-Holland, 1497-1546.

Bundesbank, 2015, Financial Stability Review, September.

Busch, Ramona and Christoph Memmel, 2015. Banks' net interest margin and the level of interest rates, Discussion Papers 16/2015, Deutsche Bundesbank, Research Centre.

Calomiris, Charles, and Doron Nissim 2014, Crisis-Related Shifts in the Market Valuation of Banking Activities, Journal of Financial Intermediation, 23, 400-435.

Cohen, Gregory, Seung Jung Lee, and Viktors Stebunovs, 2016, Limits to Monetary Policy Transmission at the Zero Lower Bound and Beyond: The Role of Nonbanks? Mimeo, International Finance Division, Federal Reserve Board

Coeure, Benoit, 2016. Assessing the implications of negative interest rates. Speech at Yale Financial Crisis Forum, Yale School of Management, New Haven. Full text at ecb.europe.eu.

Covas, Francisco B. Marcelo Rezende, and Cindy M. Vojtech, 2015, Why Are Net Interest Margins of Large Banks So Compressed?, FEDS Notes, October.

Dell'Ariccia, Giovanni, Luc Laeven and Robert Marquez, 2014, Monetary Policy, Leverage, and Bank Risk-Taking, Journal of Economic Theory, 149, 65-99. 
Dell'Ariccia, Giovanni, and Robert Marquez, 2013, Interest Rates and the Bank Risk taking Channel, Annual Review of Financial Economics 5(1), 123-141.

Demirgüç-Kunt, Aslı and Harry Huizinga, 1999, Determinants of commercial bank interest margins and profitability: some international evidence, World Bank Economic Review, 13 (2), $379-408$.

Deutsche Bank, 2013. Ultra-low interest rate: How Japanese banks have coped.

Drechsler, Itamar, Alexi Savov and Philipp Schnabl, 2014, The deposits channel of monetary policy, Working paper, Stern Business School, New York University.

No. 20141. , 2016, A Model of Monetary Policy and Risk Premia, NBER Working Paper

English, William B., 2002, Interest rate risk and bank net interest margins, BIS Quarterly Review, December, 67-82.

English, William B., Skander J. Van den Heuvel, and Egon Zakrajsek, 2012, Interest Rate Risk and Bank Equity Valuations, FEDS Working Paper 2012-26.

European Central Bank (ECB), 2015, Financial Stability Review, May.

Flannery, M. and C. James, 1984. The effect of interest rate changes on the common stock returns of financial institutions. Journal of Finance 39 (4), 1141-1153.

Gambacorta, Leonardo and Hyun Song Shin, 2016, Why bank capital matters for monetary policy, BIS Working Paper No. 558.

Genay, Hesna and Rich Podjasek, 2014, What is the impact of a low interest rate environment on bank profitability?, Chicago Fed Letter, 324, July.

Ho, Thomas S. Y. and Anthony Saunders, 1981, The Determinants of Bank Interest Margins: Theory and Empirical Evidence, Journal of Financial and Quantitative Analysis, 16(4), 581-600.

Kashyap, A.K, and J.C. Stein, 1995. The Impact of Monetary Policy on Bank Balance Sheets, Carnegie-Rochester Conference Series on Public Policy, 42, 151-195.

Kashyap, A.K., and J.C. Stein, 2000. What Do a Million Observations on Banks Say about the Transmission of Monetary Policy?, American Economic Review, 90, 407-428.

Landier, A., D. Sraer, and D. Thesmar, 2013. Banks' exposure to interest rate risk and the transmission of monetary policy. NBER Working Paper No. 18857.

Memmel, C., 2011. Banks' exposure to interest rate risk, their earnings from term transformation, and the dynamics of the term structure. Journal of Banking and Finance 35 (2), $282-289$.

Mester, L.J., 2008, Optimal Industrial Structure in Banking, In: Handbook of Financial Intermediation and Banking, Eds. A.W.A. Boot, and A.V. Thakor, Amsterdam: North Holland, 133-162.

Mishkin, Frederic, 2015, The Economics of Money, Banking and Financial Markets (11th Edition) Pearson. 
Ritz, R. and A. Walther, 2015. How do banks respond to increased funding uncertainty? Journal of Financial Intermediation 24 (3), 386-410.

Shin, Hyun Song, 2016, Bank capital and monetary policy transmission, remarks at the ECB and its Watchers Conference XVII, Frankfurt, April, available at BIS.org.

Yankov, Vladimir, 2014, In Search of a Risk-free Asset, Federal Reserve Board Finance and Economics Discussion Series 2014-108. 


\section{Appendix I: Effects of low interest rates: modeling}

\section{Theoretical Interpretation of NIM}

Empirically, we find that the NIMs are higher when interest rates are higher, but NIMs are more sensitive to interest rate fluctuations when the level of interest rates is lower. This empirical result is consistent with a theoretical breakdown of the components of NIM.

First, consider the definition of the NIM:

$$
\text { Net Interest Margin }=\frac{\text { Interest Income }- \text { Interest Expense }}{\text { Average Earning Assets }}
$$

By definition, interest income can be written as the product of the bank's earning assets and the interest rate on lending, $r$, while interest expense can be written as the product of the bank's interest bearing liabilities and the interest rate on borrowing, $r^{\prime}$.

$$
\text { Net Interest Margin }=\frac{\text { Avg.Earning Assets } * r-\text { Int. Bearing Liab. } * r^{\prime}}{\text { Avg.Earning Assets }}
$$

We can write interest bearing liabilities as a ratio of average earning assets, so

Int.Bearing Liab. $=\lambda *$ Avg.Earnign Assets, where $\lambda=\frac{\text { Int.Bearing Liabilities }}{\text { Avg.Earning Assets }}$

Likewise, we can define the ratio of the interest rate on borrowing and lending as: $r^{\prime}=\phi * r$, where $\phi=\frac{\text { borrowing rate }}{\text { lending rate }}$

Therefore,

$$
\text { Net Interest Margin }=\frac{\text { Avg.Earning Assets } * r-\text { Avg.Earning Assets } * \lambda * \phi * r}{\text { Average Earning Assets }}
$$

Taken together this becomes NIM $=r(1-\lambda \phi)$. In order to model how NIMs change as the interest rate level changes, it is easiest to assume a static balance sheet, i.e. that $\lambda$ is a fixed constant, which yields three cases to consider how the borrowing rate relates to the lending rate.

Case 1: $\phi$ is static (e.g., the deposit rate is an unchanging proportion of the loan rate).

If this were the case then the rate of change of NIM in relation to $r$ would be $\frac{d N I M}{d r}=1-\lambda \phi$

Because $\lambda$ and $\phi$ are both constants, the change in NIM would also be constant as $r$ changes.

Case 2: $\phi=\frac{r-a}{r}$ (e.g., the deposit rate is a fixed spread below the loan rate).

If this were the case then we can substitute in $\frac{r-a}{r}$ for $\phi$ and we find that

$$
N I M=r(1-\lambda \phi)=r\left[1-\lambda\left(\frac{r-a}{r}\right)\right]=r(1-\lambda)+\lambda a
$$

Then the rate of change of NIM in relation to $\mathrm{r}$ would be $\frac{d N I M}{d r}=1-\lambda$

Because we assume $\lambda$ to be a constant, the change in NIM would also be constant as $r$ changes. 
Case 3: $\phi=r^{\alpha-1}$, for $\alpha>1$ and $r>0$ (e.g., the deposit rate grows as a proportion of the loan rate).

If this were the case then we can substitute in $r^{\alpha-1}$ for $\phi$ and we find that

$$
N I M=r(1-\lambda \phi)=r\left(1-\lambda r^{\alpha-1}\right)=r-\lambda r^{\alpha}
$$

Then the rate of change of NIM in relation to $r$ would be $\frac{d N I M}{d r}=1-\lambda \alpha r^{\alpha-1}$

Because we assume $\lambda$ and $\alpha$ to be constant, the change in NIM would shrink as $\mathrm{r}$ increases, and would be greater when $r$ is lower. In other words, the NIM would be more sensitive to changes in the interest rate when the interest rate is closer to zero.

Conclusion: Given our empirical results, we reject cases 1 and 2 as our tests are consistent with case 3. This result implies that there is an important non-linearity in the mapping of the shortterm interest rate to the lending and borrowing interest rates. 


\section{Figure 1: Range of 3-month Sovereign Yields by Country}

25

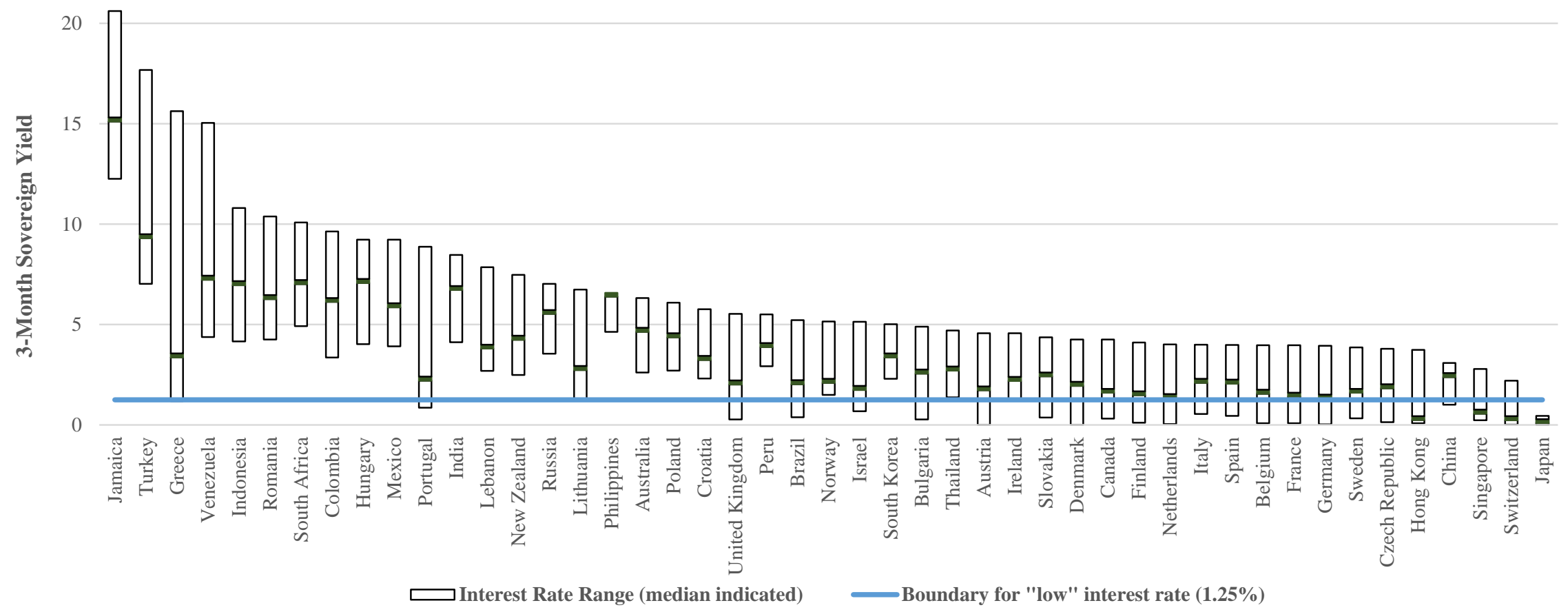

Notes: This figure reports the range of the 3-month soveign yields by country, averaged yearly from 2005 to 2013. 
Figure 2: Classification of Countries by Level of 3-month Sovereign Yield

\begin{tabular}{|c|c|c|}
\hline \multicolumn{3}{|c|}{2005} \\
\hline Low & \multicolumn{2}{|c|}{ High } \\
\hline \multirow{21}{*}{$\begin{array}{c}\text { Japan } \\
\text { Switzerland }\end{array}$} & Australia & Italy \\
\hline & Austria & Jamaica \\
\hline & Belgium & Lebanon \\
\hline & Brazil & Lithuania \\
\hline & Bulgaria & Mexico \\
\hline & Canada & Netherlands \\
\hline & China & New Zealand \\
\hline & Colombia & Norway \\
\hline & Croatia & Philippines \\
\hline & Czech Republic & Poland \\
\hline & Denmark & Portugal \\
\hline & Finland & South Korea \\
\hline & France & Singapore \\
\hline & Germany & Slovakia \\
\hline & Greece & South Africa \\
\hline & Hong Kong & Spain \\
\hline & Hungary & Sweden \\
\hline & India & Thailand \\
\hline & Indonesia & Turkey \\
\hline & Ireland & United Kingdom \\
\hline & Israel & Venezuela \\
\hline 2 & & \\
\hline
\end{tabular}

\begin{tabular}{|c|cc|}
\multicolumn{1}{c}{ Low } & \multicolumn{2}{c}{ High } \\
\hline Belgium & Australia & Romania \\
Canada & Austria & Russia \\
China & Brazil & South Africa \\
Finland & Bulgaria & Thailand \\
France & Colombia & Turkey \\
Germany & Croatia & Venezuela \\
Greece & Czech Republic & \\
Hong Kong & Denmark & \\
Israel & Hungary & \\
Italy & India & \\
Japan & Indonesia & \\
Netherlands & Ireland & \\
Portugal & Jamaica \\
Singapore & Lebanon \\
Slovakia & Lithuania \\
Spain & Mexico \\
Sweden & New Zealand \\
Switzerland & Norway \\
United Kingdom & Peru \\
& Poland \\
& South Korea \\
\hline 19 & \\
\hline
\end{tabular}

\begin{tabular}{|c|c|}
\multicolumn{1}{c}{ Low } & \multicolumn{1}{c}{ High } \\
\hline Austria & Australia \\
Belgium & China \\
Brazil & Colombia \\
Bulgaria & Greece \\
Canada & Hungary \\
Czech Republic & India \\
Denmark & Indonesia \\
Finland & Ireland \\
France & Lebanon \\
Germany & Mexico \\
Hong Kong & New Zealand \\
Italy & Norway \\
Japan & Peru \\
Netherlands & Poland \\
Portugal & South Korea \\
Singapore & Romania \\
Slovakia & Russia \\
Spain & South Africa \\
Sweden & Thailand \\
Switzerland & Turkey \\
United Kingdom & Venezuela \\
\hline 21 & 21 \\
\hline
\end{tabular}

Notes: This figure reports whether countries are coded in the High or Low environments in 2005, 2009, and 2013. This classification is based on whether the yearly average 3-month yield is above or below 1.25 percent, respectively. 
Table 1: Definitions

3-Month Sovereign Yield

Spread: 10yr - 3mo Yield

Interest Income Margin

Interest Expense Margin

\begin{tabular}{ll}
\hline Panel B: Macro Controls & The annual percentage change in a country's real gross domestic product. \\
\hline PDP Growth & \\
\hline Panel C: Bank-level Controls & $\begin{array}{l}\text { This ratio is deposits and short-term funding expressed as a percentage of total liabilities. } \\
\text { Deposits and short-term funding includes total customer deposits, deposits from banks, } \\
\text { money market instruments, CDs, and other deposits. }\end{array}$ \\
\hline Equity over Assets & $\begin{array}{l}\text { This ratio is the total equity expressed as a percentage of total assets. Total equity includes } \\
\text { common equity, non-controlling interest, securities revaluation reserves, foreign exchange } \\
\text { revaluation reserves, and other revaluation reserves. }\end{array}$ \\
\hline & $\begin{array}{l}\text { This ratio is total securities expressed as a percentage of total assets. Total securities } \\
\text { includes reverse repos and cash collateral, trading securities, all in-the-money trading } \\
\text { derivatives and derivatives recognized for hedging (less the value of netting arrangements), Bankscope } \\
\text { available for sale securities, held to maturity securities, at-equity investments, and other } \\
\text { securities. }\end{array}$ \\
\hline
\end{tabular}

Panel D: Bank Classifications

Bank

Must be categorized by Bankscope as a Bank Holding \& Holding Company, Commercial Bank, Savings Bank, or Cooperative Bank. Data is unconsolidated such that Domestic Ultimate Owners are prioritized while Global Ultimate Owners are excluded where possible.

Large and Small Banks A bank is classified as "large" if it is one of the largest banks comprising 80 percent of a banking sector's assets in any year of the sample, 2005-2013, and classified as "small" otherwise.

The annual average of a country's implied 3-month sovereign bond yield. Implied yields are calculated for each day by Bloomberg's Fair Value market curve.

The difference between a country's average 10-year implied sovereign bond yield and that country's average 3-month implied sovereign bond yield in a particular year.

Bloomberg

A country is classified as being in a "low" rate environment if its average 3-month implied sovereign yield for that year was less than or equal to 1.25 percent (chosen because this is roughly equal to the median three-month implied sovereign yield of all country-year observation pairs in the dataset), and is classified as being in a "high" rate environment

Authors otherwise.

This ratio is the net interest income expressed as a percentage of average total earning assets. Net interest income includes gross interest and dividend income minus total interest expense. Total earning assets is the sum of total loans, total securities, investments in property, and earning assets not otherwise categorized, including non-current assets held for sale which are not loans. This ratio is the net income expressed as a percentage of average total assets.

This ratio is the interest income expressed as a percentage of average earning assets. Interest income includes interest income on loans, dividend income, and other interest income. Total earning assets is the sum of total loans, total securities, investments in property, and earning Bankscope assets not otherwise categorized, including non-current assets held for sale which are not loans.

This ratio is the interest expense expressed as a percentage of average interest-bearing liabilities. Interest expense includes interest expense on customer deposits, preferred dividends paid and declared, and other interest expense. Interest-bearing liabilities includes total deposits, money market and short-term funding, total long-term funding, out-of-theBankscope money trading and hedging derivatives (less the value of netting arrangements), and trading liabilities. 
Table 2: Summary Statistics

\begin{tabular}{|c|c|c|c|c|c|c|c|c|}
\hline \multicolumn{9}{|c|}{$\begin{array}{l}\text { Panel A: Summary Statistics - Observation Level - All Countries } \\
\text { Standard }\end{array}$} \\
\hline & Mean & Median & Deviation & Minimum & Maximum & Observations & Banks & Countries \\
\hline \multicolumn{9}{|l|}{ Bank Variables } \\
\hline Net Interest Margin & 2.76 & 2.36 & 1.91 & -9.1 & 19.6 & 27,216 & 3,385 & 47 \\
\hline Return on Assets & 0.52 & 0.29 & 1.06 & -14.1 & 15.7 & 27,216 & 3,385 & 47 \\
\hline Interest Income Margin & 4.89 & 4.28 & 3.25 & -2.9 & 26.4 & 27,216 & 3,385 & 47 \\
\hline Interest Expense Margin & 2.29 & 1.86 & 2.07 & -6.5 & 15.7 & 27,216 & 3,385 & 47 \\
\hline Deposits over Liabilities & 87.73 & 94.90 & 16.09 & 4.2 & 100.0 & 27,216 & 3,385 & 47 \\
\hline Equity over Assets & 8.68 & 7.21 & 6.13 & 0.0 & 53.7 & 27,216 & 3,385 & 47 \\
\hline Securities over Assets & 20.20 & 19.35 & 14.73 & 0.0 & 96.6 & 27,216 & 3,385 & 47 \\
\hline \multicolumn{9}{|l|}{ Country Variables } \\
\hline 3-Month Sovereign Yield & 1.94 & 0.76 & 2.16 & 0.0 & 20.6 & 27,216 & 3,385 & 47 \\
\hline Spread: 10yr - 3mo Yield & 1.65 & 1.43 & 1.11 & -1.2 & 12.7 & 27,216 & 3,385 & 47 \\
\hline GDP Growth & 1.50 & 1.69 & 3.35 & -8.9 & 15.2 & 27,216 & 3,385 & 47 \\
\hline
\end{tabular}

Panel B: Summary Statistics - Bank Level - Low \& High Countries

\begin{tabular}{lcccccc} 
& $\begin{array}{c}\text { High } \\
\text { Mean }\end{array}$ & $\begin{array}{c}\text { Low } \\
\text { Mean }\end{array}$ & Difference & T-stat & $\begin{array}{c}\text { High } \\
\text { Observations }\end{array}$ & $\begin{array}{c}\text { Low } \\
\text { Observations }\end{array}$ \\
\hline Bank Variables & & & & & & \\
\hline Net Interest Margin & 2.58 & 2.37 & 0.21 & 5.60 & 2,162 & 2,166 \\
Return on Assets & 0.49 & 0.35 & 0.14 & 5.88 & 2,162 & 2,166 \\
Interest Income Margin & 5.10 & 4.02 & 1.08 & 19.47 & 2,162 & 2,166 \\
Interest Expense Margin & 2.72 & 1.78 & 0.94 & 23.86 & 2,162 & 2,166 \\
Deposits over Liabilities & 86.71 & 87.89 & -1.19 & -2.88 & 2,162 & 2,166 \\
Equity over Assets & 8.14 & 8.64 & -0.50 & -3.09 & 2,162 & 2,166 \\
Securities over Assets & 19.26 & 21.64 & -2.38 & -5.56 & 2,162 & 2,166 \\
\hline Country Variables & & & & & & 2,162 \\
\hline 3-Month Sovereign Yield & 3.02 & 0.43 & 2.59 & 200.74 & 2,166 \\
Spread: 10yr - 3mo Yield & 1.04 & 2.35 & -1.32 & -66.42 & 2,162 & 2,166 \\
GDP Growth & 1.93 & 0.50 & 1.43 & 26.72 & 2,162 & 2,166 \\
\hline
\end{tabular}

*Restricted to banks in countries that experienced both low and high interest rate environments: Austria, Belgium, Brazil, Bulgaria, Canada, China, the Czech Republic, Denmark, Finland, France, Germany, Hong Kong, Israel, Italy, the Netherlands, Portugal, Singapore, Slovakia, Spain, Sweden, Switzerland, and the United Kingdom.

Panel C: Correlations - Bank-Year Observations - Full Sample

\begin{tabular}{l|ccc} 
& $\begin{array}{c}\text { 3-Month } \\
\text { Sovereign } \\
\text { Yield }\end{array}$ & $\begin{array}{c}\text { Spread: } \\
\text { 10yr - }\end{array}$ & $\begin{array}{c}\text { GDo Yield } \\
\text { Growth }\end{array}$ \\
\hline Net Interest Margin & 0.537 & 0.237 & 0.159 \\
Return on Assets & 0.358 & 0.067 & 0.192 \\
Interest Income Margin & 0.720 & 0.209 & 0.221 \\
Interest Expense Margin & 0.687 & 0.136 & 0.211 \\
Deposits over Liabilities & -0.355 & -0.247 & 0.005 \\
Equity over Assets & 0.319 & 0.219 & 0.055 \\
Securities over Assets & -0.171 & -0.013 & -0.042 \\
\hline
\end{tabular}


Table 3: Base Regression Results for Net Interest Margin

Net Interest Margin (p.p.)

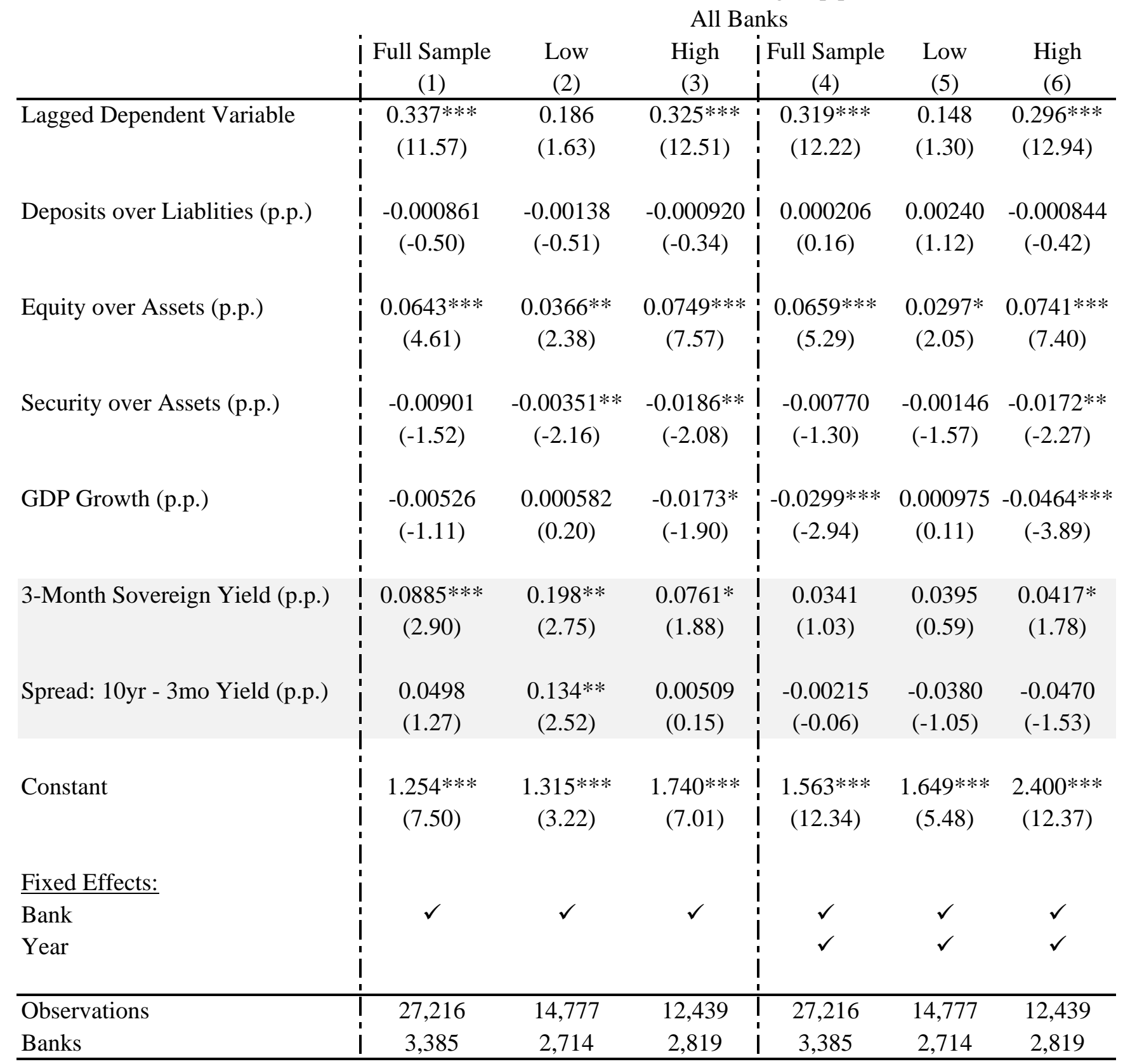

Notes: Our base sample includes 3,385 banks from 47 countries from 2005 to 2013. Unconsolidated bank-level balance sheets and income statements are reported by Bankscope. Interest rates are calculated as the annual average of daily implied sovereign yields reported by Bloomberg. Columns (2) and (5) include only those observations in a Low yield environment, where the 3-month sovereign yield is at or below 1.25 percent. Columns (3) and (6) include only those observations in a High yield environment, where the 3-month sovereign yield is above 1.25 percent. Coumns (4)-(6) include time fixed effects. Standard errors are clustered at the country level and t-statistics are reported in parentheses. All regressions include bank fixed-effects. 


\section{Table 4: Regression Results for Interest Income and Expense Ratios by Low and High Interest}

Rate Environment

\begin{tabular}{|c|c|c|c|c|c|c|}
\hline & \multicolumn{3}{|c|}{ Interest Income Margin (p.p) } & \multicolumn{3}{|c|}{ Interest Expense Margin (p.p) } \\
\hline & $\begin{array}{c}\text { Full Sample } \\
(1)\end{array}$ & $\begin{array}{l}\text { Low } \\
(2) \\
\end{array}$ & $\begin{array}{c}\text { High } \\
(3)\end{array}$ & $\begin{array}{c}\text { Full Sample } \\
\text { (4) }\end{array}$ & $\begin{array}{c}\text { Low } \\
(5)\end{array}$ & $\begin{array}{c}\text { High } \\
(6) \\
\end{array}$ \\
\hline Lagged Dependent Variable & $\begin{array}{c}0.293^{* * *} \\
(4.70)\end{array}$ & $\begin{array}{c}0.220 * * * \\
(3.90)\end{array}$ & $\begin{array}{c}0.305^{* * *} \\
(5.37)\end{array}$ & $\begin{array}{c}0.287 * * * \\
(2.93)\end{array}$ & $\begin{array}{c}0.238 * * * \\
(4.83)\end{array}$ & $\begin{array}{c}0.280 * * * \\
(2.83)\end{array}$ \\
\hline Deposits over Liablities (p.p.) & $\begin{array}{c}-0.00781 \\
(-1.47)\end{array}$ & $\begin{array}{c}0.00578^{* *} \\
(2.37)\end{array}$ & $\begin{array}{c}-0.0173 * * * \\
(-3.45)\end{array}$ & $\begin{array}{l}-0.00852 \\
(-1.30)\end{array}$ & $\begin{array}{c}0.00674 * \\
(2.05)\end{array}$ & $\begin{array}{c}-0.0193 * * * \\
(-3.53)\end{array}$ \\
\hline Equity over Assets (p.p.) & $\begin{array}{c}0.0361^{* *} \\
(2.35)\end{array}$ & $\begin{array}{r}0.0140 \\
(1.05)\end{array}$ & $\begin{array}{c}0.0501 * * * \\
(5.31)\end{array}$ & $\begin{array}{c}-0.000810 \\
(-0.12)\end{array}$ & $\begin{array}{c}-0.00994 \\
(-1.58)\end{array}$ & $\begin{array}{l}0.00824^{* * *} \\
\quad(2.90)\end{array}$ \\
\hline Security over Assets (p.p.) & $\begin{array}{c}-0.0125 \\
(-1.57)\end{array}$ & $\begin{array}{c}-0.00235 \\
(-0.79)\end{array}$ & $\begin{array}{c}-0.0233^{*} \\
(-1.79)\end{array}$ & $\begin{array}{c}-0.00267 \\
(-0.70)\end{array}$ & $\begin{array}{c}0.00129 \\
(0.39)\end{array}$ & $\begin{array}{c}-0.00419 \\
(-0.69)\end{array}$ \\
\hline GDP Growth (p.p.) & $\begin{array}{c}-0.0125 \\
(-0.88)\end{array}$ & $\begin{array}{c}-0.0183^{* *} \\
(-2.79)\end{array}$ & $\begin{array}{c}-0.0231 \\
(-0.60)\end{array}$ & $\begin{array}{c}-0.00851 \\
(-0.45)\end{array}$ & $\begin{array}{c}-0.0181 * * * \\
(-3.71)\end{array}$ & $\begin{array}{c}-0.00618 \\
(-0.13)\end{array}$ \\
\hline 3-Month Sovereign Yield (p.p.) & $\begin{array}{c}0.362 * * * \\
(9.80)\end{array}$ & $\begin{array}{c}0.673^{* * *} \\
(5.24)\end{array}$ & $\begin{array}{c}0.301 * * * \\
(4.33)\end{array}$ & $\begin{array}{c}0.303^{* * *} \\
(11.94)\end{array}$ & $\begin{array}{c}0.514^{* * *} \\
(5.15)\end{array}$ & $\begin{array}{c}0.253^{* * *} \\
(4.44)\end{array}$ \\
\hline Spread: 10yr - 3mo Yield (p.p.) & $\begin{array}{l}0.0501 \\
(0.46)\end{array}$ & $\begin{array}{c}0.212 * * \\
(2.11)\end{array}$ & $\begin{array}{l}0.0157 \\
(0.09)\end{array}$ & $\begin{array}{c}0.0138 \\
(0.15)\end{array}$ & $\begin{array}{l}0.0717 \\
(0.91)\end{array}$ & $\begin{array}{c}0.0260 \\
(0.16)\end{array}$ \\
\hline Constant & $\begin{array}{c}3.263^{* * *} \\
(8.19)\end{array}$ & $\begin{array}{c}1.275^{* * *} \\
(4.82)\end{array}$ & $\begin{array}{c}4.955 * * * \\
(11.36)\end{array}$ & $\begin{array}{l}1.818 * * * \\
(3.49)\end{array}$ & $\begin{array}{c}0.0114 \\
(0.03)\end{array}$ & $\begin{array}{c}3.173 * * * \\
(7.46)\end{array}$ \\
\hline$\frac{\text { Fixed Effects: }}{\text { Bank }}$ & $\checkmark$ & $\checkmark$ & $\checkmark$ & $\checkmark$ & $\checkmark$ & $\checkmark$ \\
\hline Observations & 27,216 & 14,777 & 12,439 & 27,216 & 14,777 & 12,439 \\
\hline Banks & 3,385 & 2,714 & 2,819 & 3,385 & 2,714 & 2,819 \\
\hline
\end{tabular}

Notes: Our base sample includes 3,385 banks from 47 countries from 2005 to 2013. Unconsolidated bank-level balance sheets and income statements are reported by Bankscope. Interest rates are calculated as the annual average of daily implied sovereign yields reported by Bloomberg. Columns (2) and (5) include only those observations in a Low yield environment, where the 3-month sovereign yield is at or below 1.25 percent. Columns (3) and (6) include only those observations in a High yield environment, where the 3-month sovereign yield is above 1.25 percent. Standard errors are clustered at the country level and t-statistics are reported in parentheses. All regressions include bank fixed-effects. 
Table 5: Regression Results for Large and Small banks by Low and High Interest Rate Environment

\begin{tabular}{|c|c|c|c|c|c|c|}
\hline \multirow{3}{*}{ | } & \multicolumn{6}{|c|}{ Net Interest Margin (p.p.) } \\
\hline & \multicolumn{3}{|c|}{ Small Banks } & \multicolumn{2}{|c|}{$\mathrm{La}$} & \multirow[b]{2}{*}{$\begin{array}{l}\text { High } \\
(6)\end{array}$} \\
\hline & $\begin{array}{c}\text { Full Sample } \\
\text { (1) }\end{array}$ & $\begin{array}{c}\text { Low } \\
(2)\end{array}$ & $\begin{array}{l}\text { High } \\
(3)\end{array}$ & $\begin{array}{l}\text { Full Sample } \\
\text { (4) }\end{array}$ & $\begin{array}{c}\text { Low } \\
(5)\end{array}$ & \\
\hline Lagged Dependent Variable & $\begin{array}{c}0.338 * * * \\
(10.82)\end{array}$ & $\begin{array}{l}0.180 \\
(1.54)\end{array}$ & $\begin{array}{c}0.328 * * * \\
(11.72)\end{array}$ & $\begin{array}{c}0.308^{* * *} \\
(5.33)\end{array}$ & $\begin{array}{c}0.253^{* * *} \\
(3.27)\end{array}$ & $\begin{array}{c}0.286 * * * \\
(4.48)\end{array}$ \\
\hline Deposits over Liablities (p.p.) & $\begin{array}{c}-0.00101 \\
(-0.50)\end{array}$ & $\begin{array}{c}-0.00309 \\
(-1.46)\end{array}$ & $\begin{array}{c}-0.000744 \\
(-0.26)\end{array}$ & $\begin{array}{c}0.00177 \\
(0.60)\end{array}$ & $\begin{array}{r}0.0107 \\
(1.14)\end{array}$ & $\begin{array}{c}0.0000942 \\
(0.03)\end{array}$ \\
\hline Equity over Assets (p.p.) & $\begin{array}{c}0.0675^{* * *} \\
(5.03)\end{array}$ & $\begin{array}{c}0.0361^{* *} \\
(2.17)\end{array}$ & $\begin{array}{c}0.0800 * * * \\
(12.63)\end{array}$ & $\begin{array}{l}0.0281 \\
(1.52)\end{array}$ & $\begin{array}{c}0.0306^{*} \\
(1.94)\end{array}$ & $\begin{array}{l}0.0167 \\
(0.52)\end{array}$ \\
\hline Security over Assets (p.p.) & $\begin{array}{c}-0.00886 \\
(-1.35)\end{array}$ & $\begin{array}{c}-0.00338^{*} \\
(-1.94)\end{array}$ & $\begin{array}{c}-0.0185^{*} \\
(-1.80)\end{array}$ & $\begin{array}{c}-0.00806^{*} \\
(-1.82)\end{array}$ & $\begin{array}{c}-0.00114 \\
(-0.56)\end{array}$ & $\begin{array}{c}-0.0166^{* *} \\
(-2.16)\end{array}$ \\
\hline GDP Growth (p.p.) & $\begin{array}{c}-0.00624 \\
(-1.16)\end{array}$ & $\begin{array}{c}0.000777 \\
(0.26)\end{array}$ & $\begin{array}{c}-0.0237 * * \\
(-2.66)\end{array}$ & $\begin{array}{c}0.00147 \\
(0.27)\end{array}$ & $\begin{array}{c}0.000437 \\
(0.07)\end{array}$ & $\begin{array}{c}0.00590 \\
(0.52)\end{array}$ \\
\hline 3-Month Sovereign Yield (p.p.) & $\begin{array}{c}0.0909 * * * \\
(2.76)\end{array}$ & $\begin{array}{c}0.197 * * \\
(2.58)\end{array}$ & $\begin{array}{c}0.0699 \\
(1.49)\end{array}$ & $\begin{array}{c}0.0691^{* * *} \\
(3.31)\end{array}$ & $\begin{array}{c}0.153^{* *} \\
(2.61)\end{array}$ & $\begin{array}{c}0.0789 * * * \\
\quad(2.99)\end{array}$ \\
\hline Spread: 10yr - 3mo Yield (p.p.) & $\begin{array}{l}0.0484 \\
(1.18)\end{array}$ & $\begin{array}{c}0.146^{* *} \\
(2.63)\end{array}$ & $\begin{array}{c}-0.0115 \\
(-0.35)\end{array}$ & $\begin{array}{c}0.0589 * \\
(1.71)\end{array}$ & $\begin{array}{c}0.0563 \\
(0.82)\end{array}$ & $\begin{array}{c}0.0636 \\
(1.56)\end{array}$ \\
\hline Constant & $\begin{array}{c}1.235^{* * *} \\
(7.81)\end{array}$ & $\begin{array}{c}1.498 * * * \\
(4.88)\end{array}$ & $\begin{array}{c}1.710 * * * \\
(7.15)\end{array}$ & $\begin{array}{c}1.334^{* * *} \\
(3.09)\end{array}$ & $\begin{array}{c}-0.0170 \\
(-0.02)\end{array}$ & $\begin{array}{c}3.173^{* * * *} \\
(7.46)\end{array}$ \\
\hline$\frac{\text { Fixed Effects: }}{\text { Bank }}$ & $\begin{array}{l}1 \\
1\end{array}$ & $\checkmark$ & $\checkmark$ & $\checkmark$ & $\checkmark$ & $\checkmark$ \\
\hline Observations & 23,895 & 13,366 & 10,529 & 3,321 & 1,411 & 1,910 \\
\hline Banks & 2,973 & 2,439 & 2,460 & 412 & 275 & 359 \\
\hline
\end{tabular}

Notes: Our base sample includes 3,385 banks from 47 countries from 2005 to 2013 . Unconsolidated bank-level balance sheets and income statements are reported by Bankscope. Interest rates are calculated as the annual average of daily implied sovereign yields reported by Bloomberg. Coumns (4)-(6) include only those banks classified as Large, i.e. one of the largest banks comprising 80 percent of its banking system's assets in any given year of the sample. Coumns (1)-(3) include only those banks classified as Small, i.e. banks that were not classified as Large. Columns (2) and (5) include only those observations in a Low yield environment, where the 3-month sovereign yield is at or below 1.25 percent. Columns (3) and (6) ainclude only those observations in a High yield environment, where the 3-month sovereign yield is above 1.25 percent. Standard errors are clustered at the coutnry level and t-statistics are reported in parentheses. All regressions include bank fixed-effects. 
Table 6: Regression Results for Interest Income and Expense Ratios by Asset and Liability Maturity of Banks and Low and High Interest Rate Environment

\begin{tabular}{|c|c|c|c|c|c|c|c|c|c|c|c|c|}
\hline & \multicolumn{6}{|c|}{ Interest Income Margin (p.p.) } & \multicolumn{6}{|c|}{ Interest Expense Margin (p.p.) } \\
\hline & \multicolumn{2}{|c|}{ Full Sample } & \multicolumn{2}{|c|}{ Low Yield Environment } & \multicolumn{2}{|c|}{ High Yield Environment } & \multicolumn{2}{|c|}{ Full Sample } & \multicolumn{2}{|c|}{ Low Yield Environment } & \multicolumn{2}{|c|}{ High Yield Environment } \\
\hline & $\begin{array}{l}\text { Short } \\
(1)\end{array}$ & $\begin{array}{l}\text { Long } \\
(2)\end{array}$ & $\begin{array}{l}\text { Short } \\
\text { (3) }\end{array}$ & $\begin{array}{l}\text { Long } \\
(4)\end{array}$ & $\begin{array}{c}\text { Short } \\
(5)\end{array}$ & $\begin{array}{c}\text { Long } \\
(6)\end{array}$ & $\begin{array}{l}\text { Short } \\
(7)\end{array}$ & $\begin{array}{c}\text { Long } \\
(8)\end{array}$ & $\begin{array}{c}\text { Short } \\
(9)\end{array}$ & $\begin{array}{c}\text { Long } \\
(10) \\
\end{array}$ & $\begin{array}{c}\text { Short } \\
(11) \\
\end{array}$ & $\begin{array}{c}\text { Long } \\
(12) \\
\end{array}$ \\
\hline Lagged Dependent Variable & $\begin{array}{l}0.153 \\
(1.05)\end{array}$ & $\begin{array}{c}0.244^{* * *} \\
(3.42)\end{array}$ & $\begin{array}{c}0.259 * * * \\
(3.83)\end{array}$ & $\begin{array}{c}0.214^{* * *} \\
(4.98)\end{array}$ & $\begin{array}{l}0.0339 \\
(0.39)\end{array}$ & $\begin{array}{c}0.156^{* *} \\
(2.84)\end{array}$ & $\begin{array}{l}0.107 \\
(0.65)\end{array}$ & $\begin{array}{l}0.245^{*} \\
(2.17)\end{array}$ & $\begin{array}{l}0.147 \\
(1.83)\end{array}$ & $\begin{array}{c}0.288^{* * *} \\
(6.75)\end{array}$ & $\begin{array}{l}0.0403 \\
(0.63)\end{array}$ & $\begin{array}{l}0.0248 \\
(0.28)\end{array}$ \\
\hline Deposits over Liablities (p.p.) & $\begin{array}{c}0.000126 \\
(0.02)\end{array}$ & $\begin{array}{c}-0.000433 \\
(-0.06)\end{array}$ & $\begin{array}{l}0.0115^{* * *} \\
\quad(4.64)\end{array}$ & $\begin{array}{c}0.00175 \\
(0.32)\end{array}$ & $\begin{array}{c}-0.00730 \\
(-1.59)\end{array}$ & $\begin{array}{c}0.00383 \\
(0.42)\end{array}$ & $\begin{array}{l}0.000169 \\
(0.04)\end{array}$ & $\begin{array}{c}0.00156 \\
(0.43)\end{array}$ & $\begin{array}{c}0.00569 \\
(1.21)\end{array}$ & $\begin{array}{c}0.0115^{* * *} \\
(4.05)\end{array}$ & $\begin{array}{c}-0.00350 \\
(-0.60)\end{array}$ & $\begin{array}{c}-0.00952 \\
(-1.09)\end{array}$ \\
\hline Equity over Assets (p.p.) & $\begin{array}{l}0.0125 \\
(0.92)\end{array}$ & $\begin{array}{c}0.00441 \\
(0.24)\end{array}$ & $\begin{array}{c}0.00635 \\
(0.29)\end{array}$ & $\begin{array}{c}0.000276 \\
(0.01)\end{array}$ & $\begin{array}{c}0.0422 * \\
(2.08)\end{array}$ & $\begin{array}{c}-0.0105 \\
(-0.41)\end{array}$ & $\begin{array}{c}-0.0114 \\
(-1.29)\end{array}$ & $\begin{array}{c}-0.0174 * * \\
(-2.90)\end{array}$ & $\begin{array}{c}-0.00263 \\
(-0.43)\end{array}$ & $\begin{array}{c}-0.0117 \\
(-0.74)\end{array}$ & $\begin{array}{c}-0.0158 \\
(-0.75)\end{array}$ & $\begin{array}{c}-0.00832 \\
(-0.29)\end{array}$ \\
\hline Security over Assets (p.p.) & $\begin{array}{c}-0.00442 \\
(-1.11)\end{array}$ & $\begin{array}{c}-0.000374 \\
(-0.13)\end{array}$ & $\begin{array}{c}-0.00178 \\
(-0.32)\end{array}$ & $\begin{array}{c}0.00192 \\
(0.39)\end{array}$ & $\begin{array}{c}0.00845 \\
(1.13)\end{array}$ & $\begin{array}{c}0.0105 \\
(0.67)\end{array}$ & $\begin{array}{c}-0.00267 \\
(-0.61)\end{array}$ & $\begin{array}{c}0.00300 \\
(0.63)\end{array}$ & $\begin{array}{c}-0.00197 \\
(-0.32)\end{array}$ & $\begin{array}{c}0.00715 \\
(1.25)\end{array}$ & $\begin{array}{c}0.00808^{*} \\
(1.94)\end{array}$ & $\begin{array}{l}0.0121 \\
(1.50)\end{array}$ \\
\hline GDP Growth (p.p.) & $\begin{array}{c}-0.0385 * \\
(-2.16)\end{array}$ & $\begin{array}{c}-0.0321^{* *} \\
(-2.68)\end{array}$ & $\begin{array}{c}-0.0195 * * \\
(-2.60)\end{array}$ & $\begin{array}{c}-0.0228 * \\
(-2.23)\end{array}$ & $\begin{array}{c}-0.145^{* * *} \\
(-6.26)\end{array}$ & $\begin{array}{c}-0.121^{* * *} \\
(-4.50)\end{array}$ & $\begin{array}{c}-0.0495 * \\
(-2.23)\end{array}$ & $\begin{array}{c}-0.0349 * * \\
(-2.93)\end{array}$ & $\begin{array}{c}-0.0332 * * \\
(-2.81)\end{array}$ & $\begin{array}{c}-0.0168^{* * * *} \\
(-3.81)\end{array}$ & $\begin{array}{c}-0.157 * * * \\
(-11.53)\end{array}$ & $\begin{array}{c}-0.169 * * * \\
(-8.53)\end{array}$ \\
\hline 3-Month Sovereign Yield (p.p.) & $\begin{array}{c}0.447 * * * \\
(5.88)\end{array}$ & $\begin{array}{c}0.375^{* * *} \\
(7.32)\end{array}$ & $\begin{array}{c}0.936^{* * *} \\
(4.80)\end{array}$ & $\begin{array}{c}0.656^{* *} \\
(3.31)\end{array}$ & $\begin{array}{l}0.318 \\
(1.29)\end{array}$ & $\begin{array}{l}0.220 \\
(0.89)\end{array}$ & $\begin{array}{c}0.419 * * * \\
(7.64)\end{array}$ & $\begin{array}{c}0.327^{* * *} \\
(7.14)\end{array}$ & $\begin{array}{c}0.765 * * * \\
(5.34)\end{array}$ & $\begin{array}{c}0.518^{* *} \\
(3.02)\end{array}$ & $\begin{array}{c}0.518^{* * *} \\
(4.41)\end{array}$ & $\begin{array}{l}0.510^{*} \\
(2.24)\end{array}$ \\
\hline Spread: 10yr - 3mo Yield (p.p.) & $\begin{array}{c}0.0165 \\
(0.09)\end{array}$ & $\begin{array}{c}0.0761 \\
(0.52)\end{array}$ & $\begin{array}{l}0.0950 \\
(0.85)\end{array}$ & $\begin{array}{l}0.201 \\
(1.38)\end{array}$ & $\begin{array}{c}-0.409 * * \\
(-2.94)\end{array}$ & $\begin{array}{c}-0.373^{* *} \\
(-2.60)\end{array}$ & $\begin{array}{l}0.0160 \\
(0.16)\end{array}$ & $\begin{array}{c}-0.0360 \\
(-0.31)\end{array}$ & $\begin{array}{c}0.0822 \\
(0.92)\end{array}$ & $\begin{array}{c}0.0795 \\
(0.74)\end{array}$ & $\begin{array}{l}-0.118 \\
(-0.89)\end{array}$ & $\begin{array}{l}-0.112 \\
(-0.48)\end{array}$ \\
\hline Constant & $\begin{array}{c}3.143^{* *} \\
(2.62)\end{array}$ & $\begin{array}{c}2.674^{* * *} \\
(5.15)\end{array}$ & $\begin{array}{c}1.265^{* * *} \\
(3.78)\end{array}$ & $\begin{array}{c}2.162 * * * \\
(5.12)\end{array}$ & $\begin{array}{c}4.946^{* * *} \\
(6.31)\end{array}$ & $\begin{array}{c}3.780^{* *} \\
(2.35)\end{array}$ & $\begin{array}{l}1.385 \\
(1.82)\end{array}$ & $\begin{array}{c}1.220^{* *} \\
(2.82)\end{array}$ & $\begin{array}{l}0.445 \\
(0.79)\end{array}$ & $\begin{array}{l}-0.207 \\
(-0.83)\end{array}$ & $\begin{array}{c}1.674 * * * \\
(4.80)\end{array}$ & $\begin{array}{c}2.279^{* * *} \\
(3.40)\end{array}$ \\
\hline$\frac{\text { Fixed Effects: }}{\text { Bank }}$ & $\checkmark$ & $\checkmark$ & $\checkmark$ & $\checkmark$ & $\checkmark$ & $\checkmark$ & $\checkmark$ & $\checkmark$ & $\checkmark$ & $\checkmark$ & $\checkmark$ & $\checkmark$ \\
\hline Observations & 6,908 & 8,230 & 3,773 & 4,759 & 3,135 & 3,471 & 7,539 & 8,486 & 4,184 & 4,729 & 3,355 & 3,757 \\
\hline Banks & 837 & 985 & 789 & 948 & 829 & 981 & 924 & 1,027 & 882 & 985 & 918 & 1,019 \\
\hline
\end{tabular}

Notes: This sample includes only banks with sufficient maturity data from 2005 to 2013, which is 1,822 banks for columns (1)-(6) and 1,951 banks for columns (7)-(12). Unconsolidated

bank-level balance sheets and income statements are reported by Bankscope. Interest rates are calculated as the annual average of daily implied sovereign yields reported by Bloomberg.

Columns (3), (4), (9) and (10) include only those observations in a Low yield environment, where the 3-month sovereign yield is at or below 1.25 percent. Columns (5), (6), (11) and (12)

include only those observations in a High yield environment, where the 3-month sovereign yield is above 1.25 percent. Even numbered columns include only banks classified as having a

Long balance sheet maturity, while odd numbered columns include those banks with a Short balance sheet maturity. A bank is classified as having a Long maturity if it has an average

balance sheet maturity over the sample period greater than the median maturity for banks in its country, and is classified as having a Short maturity otherwise. Assets are used to determine

maturity for the interest income margin, i.e. columns (1)-(6), whereas liabilities are used for the interest expense margin, i.e. columns (7)-(12). Standard errors are clustered at the bank level and t-statistics are reported in parentheses. All regressions include bank fixed-effects. 
Table 7: Base Regression Results for Return on Assets

\begin{tabular}{|c|c|c|c|c|c|c|c|c|c|}
\hline & \multicolumn{9}{|c|}{ Return on Assets (p.p.) } \\
\hline & \multicolumn{3}{|c|}{ All Banks } & \multicolumn{3}{|c|}{ Large Banks } & \multicolumn{3}{|c|}{ Small Banks } \\
\hline & $\begin{array}{c}\text { Full Sample } \\
\text { (1) }\end{array}$ & $\begin{array}{c}\text { Low } \\
(2)\end{array}$ & $\begin{array}{l}\text { High } \\
\text { (3) }\end{array}$ & $\begin{array}{c}\text { Full Sample } \\
\text { (4) }\end{array}$ & $\begin{array}{l}\text { Low } \\
(5)\end{array}$ & $\begin{array}{l}\text { High } \\
(6)\end{array}$ & $\begin{array}{c}\text { Full Sample } \\
\text { (7) }\end{array}$ & $\begin{array}{c}\text { Low } \\
(8)\end{array}$ & $\begin{array}{l}\text { High } \\
(9)\end{array}$ \\
\hline Lagged Dependent Variable & $\begin{array}{c}0.0626^{*} \\
(1.89)\end{array}$ & $\begin{array}{c}0.0127 \\
(0.21)\end{array}$ & $\begin{array}{c}0.0212 \\
(0.86)\end{array}$ & $\begin{array}{l}0.0447 \\
(1.54)\end{array}$ & $\begin{array}{c}0.000631 \\
(0.02)\end{array}$ & $\begin{array}{l}0.0447 \\
(1.42)\end{array}$ & $\begin{array}{c}0.0633^{*} \\
(1.75)\end{array}$ & $\begin{array}{c}0.0125 \\
(0.19)\end{array}$ & $\begin{array}{c}0.0156 \\
(0.60)\end{array}$ \\
\hline Deposits over Liablities (p.p.) & $\begin{array}{c}0.000595 \\
(0.13)\end{array}$ & $\begin{array}{c}-0.00516 \\
(-1.11)\end{array}$ & $\begin{array}{c}0.00391 \\
(0.77)\end{array}$ & $\begin{array}{c}0.00388 \\
(0.89)\end{array}$ & $\begin{array}{c}0.0105 \\
(0.83)\end{array}$ & $\begin{array}{c}0.00667 \\
(1.54)\end{array}$ & $\begin{array}{c}0.000109 \\
(0.02)\end{array}$ & $\begin{array}{c}-0.00737^{*} \\
(-1.89)\end{array}$ & $\begin{array}{c}0.00372 \\
(0.71)\end{array}$ \\
\hline Equity over Assets (p.p.) & $\begin{array}{c}0.0524^{* * *} \\
(3.12)\end{array}$ & $\begin{array}{c}0.0882^{* * *} \\
\quad(3.76)\end{array}$ & $\begin{array}{c}0.0413^{* * *} \\
\quad(2.95)\end{array}$ & $\begin{array}{c}0.0940 * * * \\
(4.09)\end{array}$ & $\begin{array}{l}0.105^{*} \\
(1.75)\end{array}$ & $\begin{array}{c}0.101^{* * *} \\
(3.98)\end{array}$ & $\begin{array}{c}0.0485 * * * \\
(2.71)\end{array}$ & $\begin{array}{c}0.0854 * * * \\
(3.90)\end{array}$ & $\begin{array}{c}0.0357 * * \\
(2.52)\end{array}$ \\
\hline Security over Assets (p.p.) & $\begin{array}{c}0.00134 \\
(0.72)\end{array}$ & $\begin{array}{c}-0.00134 \\
(-0.56)\end{array}$ & $\begin{array}{c}0.00442 * \\
(1.73)\end{array}$ & $\begin{array}{c}0.00261 \\
(1.04)\end{array}$ & $\begin{array}{c}0.000998 \\
(0.19)\end{array}$ & $\begin{array}{c}0.00297 \\
(0.55)\end{array}$ & $\begin{array}{c}0.00108 \\
(0.54)\end{array}$ & $\begin{array}{c}-0.00109 \\
(-0.40)\end{array}$ & $\begin{array}{c}0.00437 \\
(1.53)\end{array}$ \\
\hline GDP Growth (p.p.) & $\begin{array}{c}0.0135 \\
(1.29)\end{array}$ & $\begin{array}{l}0.0140 \\
(1.57)\end{array}$ & $\begin{array}{l}0.0147 \\
(0.70)\end{array}$ & $\begin{array}{l}0.0114 \\
(1.19)\end{array}$ & $\begin{array}{c}0.0128 * \\
(1.74)\end{array}$ & $\begin{array}{c}0.00848 \\
(0.49)\end{array}$ & $\begin{array}{l}0.0139 \\
(1.29)\end{array}$ & $\begin{array}{c}0.0144 \\
(1.57)\end{array}$ & $\begin{array}{c}0.0186 \\
(0.84)\end{array}$ \\
\hline 3-Month Sovereign Yield (p.p.) & $\begin{array}{c}0.0293 \\
(1.06)\end{array}$ & $\begin{array}{l}0.0463 \\
(1.08)\end{array}$ & $\begin{array}{c}0.0285 \\
(0.50)\end{array}$ & $\begin{array}{c}0.00408 \\
(0.17)\end{array}$ & $\begin{array}{c}0.0490 \\
(0.35)\end{array}$ & $\begin{array}{l}-0.0188 \\
(-0.51)\end{array}$ & $\begin{array}{r}0.0357 \\
(1.11)\end{array}$ & $\begin{array}{c}0.0379 \\
(0.76)\end{array}$ & $\begin{array}{c}0.0521 \\
(0.75)\end{array}$ \\
\hline Spread: 10yr - 3mo Yield (p.p.) & $\begin{array}{l}-0.0550 \\
(-1.50)\end{array}$ & $\begin{array}{c}0.101^{* * *} \\
(3.04)\end{array}$ & $\begin{array}{c}-0.0928 * * \\
(-2.21)\end{array}$ & $\begin{array}{c}-0.0945^{*} \\
(-1.84)\end{array}$ & $\begin{array}{c}0.0819 \\
(1.11)\end{array}$ & $\begin{array}{c}-0.131^{* *} \\
(-2.16)\end{array}$ & $\begin{array}{c}-0.0471 \\
(-1.31)\end{array}$ & $\begin{array}{c}0.108^{* * *} \\
(3.04)\end{array}$ & $\begin{array}{c}-0.0761 \\
(-1.57)\end{array}$ \\
\hline Constant & $\begin{array}{c}-0.0379 \\
(-0.10)\end{array}$ & $\begin{array}{l}-0.101 \\
(-0.23)\end{array}$ & $\begin{array}{c}-0.0266 \\
(-0.06)\end{array}$ & $\begin{array}{l}-0.289 \\
(-0.62)\end{array}$ & $\begin{array}{l}-1.504 \\
(-1.07)\end{array}$ & $\begin{array}{l}-0.213 \\
(-0.49)\end{array}$ & $\begin{array}{c}-0.00873 \\
(-0.02)\end{array}$ & $\begin{array}{c}0.0994 \\
(0.33)\end{array}$ & $\begin{array}{l}-0.105 \\
(-0.19)\end{array}$ \\
\hline Fixed Effects: & i & & & & & & & & \\
\hline Bank & $\checkmark$ & $\checkmark$ & $\checkmark$ & $\checkmark$ & $\checkmark$ & $\checkmark$ & $\checkmark$ & $\checkmark$ & $\checkmark$ \\
\hline Observations & 27,216 & 14,777 & 12,439 & 3,321 & 1,411 & 1,910 & 23,895 & 13,366 & 10,529 \\
\hline Banks & 3,385 & 2,714 & 2,819 & 412 & 275 & 359 & 2,973 & 2,439 & 2,460 \\
\hline
\end{tabular}

Notes: Our base sample includes 3,385 banks from 47 countries from 2005 to 2013. Unconsolidated bank-level balance sheets and income statements are reported by Bankscope. Interest rates are calculated as the annual average of daily implied sovereign yields reported by Bloomberg. Columns (2) and (5) include only those observations in a Low yield environment, where the 3-month sovereign yield is at or below 1.25 percent. Columns (3) and (6) include only those observations in a High yield environment, where the 3-month sovereign yield is above 1.25 percent. Coumns (4)-(6) include time fixed effects. Standard errors are clustered at the country level and t-statistics are reported in parentheses. All regressions include bank fixedeffects. 
Table 8: Regression Results for Net Interest Margins and Return on Assets by Years in Low

\begin{tabular}{|c|c|c|c|c|c|c|}
\hline & \multicolumn{3}{|c|}{ Net Interest Margin (p.p) } & \multicolumn{3}{|c|}{ Return on Assets (p.p) } \\
\hline & (1) & $(2)$ & (3) & (4) & (5) & $(6)$ \\
\hline Deposits over Liablities (p.p.) & $\begin{array}{c}-0.00452 \\
(-1.65)\end{array}$ & $\begin{array}{c}-0.00427 \\
(-1.41)\end{array}$ & $\begin{array}{c}-0.00352 \\
(-1.19)\end{array}$ & $\begin{array}{c}-0.00727 \\
(-1.64)\end{array}$ & $\begin{array}{c}-0.00710 \\
(-1.56)\end{array}$ & $\begin{array}{c}-0.00803^{*} \\
(-1.81)\end{array}$ \\
\hline Equity over Assets (p.p.) & $\begin{array}{c}0.0280 \\
(1.37)\end{array}$ & $\begin{array}{c}0.0319 \\
(1.53)\end{array}$ & $\begin{array}{c}0.0316 \\
(1.50)\end{array}$ & $\begin{array}{c}0.0640^{* *} \\
(2.18)\end{array}$ & $\begin{array}{c}0.0667^{* *} \\
(2.27)\end{array}$ & $\begin{array}{c}0.0658 * * \\
(2.23)\end{array}$ \\
\hline Security over Assets (p.p.) & $\begin{array}{c}-0.00471^{* *} \\
(-2.56)\end{array}$ & $\begin{array}{c}-0.00589 * * \\
(-2.76)\end{array}$ & $\begin{array}{c}-0.00555^{* *} \\
(-2.74)\end{array}$ & $\begin{array}{c}-0.00278 \\
(-0.83)\end{array}$ & $\begin{array}{c}-0.00357 \\
(-1.05)\end{array}$ & $\begin{array}{c}-0.00400 \\
(-1.10)\end{array}$ \\
\hline GDP Growth (p.p.) & $\begin{array}{c}-0.00189 \\
(-0.21)\end{array}$ & $\begin{array}{c}0.00315 \\
(0.49)\end{array}$ & $\begin{array}{c}-0.0110 * \\
(-1.80)\end{array}$ & $\begin{array}{c}0.00352 \\
(0.61)\end{array}$ & $\begin{array}{c}0.00691 \\
(1.18)\end{array}$ & $\begin{array}{c}0.0150 \\
(0.91)\end{array}$ \\
\hline 3-Month Sovereign Yield (p.p.) & $\begin{array}{c}0.162 * \\
(1.99)\end{array}$ & $\begin{array}{c}-0.00281 \\
(-0.05)\end{array}$ & $\begin{array}{l}-0.156 \\
(-1.31)\end{array}$ & $\begin{array}{l}-0.0105 \\
(-0.16)\end{array}$ & $\begin{array}{l}-0.121 \\
(-1.07)\end{array}$ & $\begin{array}{l}-0.145 \\
(-1.14)\end{array}$ \\
\hline Spread: 10yr - 3mo Yield (p.p.) & $\begin{array}{c}0.0679 \\
(1.30)\end{array}$ & $\begin{array}{c}-0.0813^{*} \\
(-1.80)\end{array}$ & $\begin{array}{c}-0.148 * * * \\
(-4.16)\end{array}$ & $\begin{array}{c}0.0763 \\
(1.33)\end{array}$ & $\begin{array}{c}-0.0241 \\
(-0.64)\end{array}$ & $\begin{array}{c}-0.0419 \\
(-0.77)\end{array}$ \\
\hline Years In Low & & $\begin{array}{c}-0.0865^{* * *} \\
(-5.02)\end{array}$ & & & $\begin{array}{c}-0.0582^{*} \\
(-2.06)\end{array}$ & \\
\hline 1 Year In Fixed Effect & & & $\begin{array}{l}0.0147 \\
(0.33)\end{array}$ & & & $\begin{array}{l}-0.143 \\
(-1.09)\end{array}$ \\
\hline 2 Years In Fixed Effect & & & $\begin{array}{c}-0.0790 \\
(-1.55)\end{array}$ & & & $\begin{array}{l}-0.191 \\
(-1.34)\end{array}$ \\
\hline 3 Years In Fixed Effect & & & $\begin{array}{c}-0.375^{* * *} \\
(-4.46)\end{array}$ & & & $\begin{array}{l}-0.259 \\
(-1.59)\end{array}$ \\
\hline 4 Years In Fixed Effect & & & $\begin{array}{c}-0.398^{* * *} \\
(-4.69)\end{array}$ & & & $\begin{array}{c}-0.290^{*} \\
(-1.87)\end{array}$ \\
\hline Constant & $\begin{array}{c}2.518 * * * \\
(6.45)\end{array}$ & $\begin{array}{c}3.054^{* * *} \\
(6.85)\end{array}$ & $\begin{array}{c}3.195 * * * \\
(6.65)\end{array}$ & $\begin{array}{l}0.337 \\
(1.04)\end{array}$ & $\begin{array}{c}0.697 * * \\
(2.40)\end{array}$ & $\begin{array}{c}0.904^{* *} \\
(2.10)\end{array}$ \\
\hline Fixed Effects: & & & & & & \\
\hline Bank & $\checkmark$ & $\checkmark$ & $\checkmark$ & $\checkmark$ & $\checkmark$ & $\checkmark$ \\
\hline Observations & 8,130 & 8,130 & 8,130 & 8,130 & 8,130 & 8,130 \\
\hline Banks & 1,910 & 1,910 & 1,910 & 1,910 & 1,910 & 1,910 \\
\hline
\end{tabular}

Notes: This sample includes only banks in countries that switched from a High to Low yield environment from 2005 to 2013. Unconsolidated bank-level balance sheets and income statements are reported by Bankscope. Interest rates are calculated as the annual average of daily implied sovereign yields reported by Bloomberg. Years in Low denotes the number of years since a country's average annual implied three-month yield fell from above 1.25 percent to at or below 1.25 percent. Years in Low in these regressions ranges from 0 to 4 . Standard errors are clustered at the country level and t-statistics are reported in parentheses. Columns (3) and (6) include fixed-effects for each year since a country entered a Low rate environment. All regressions include bank fixed-effects. 
Table 9: Base Regression Results for Net Interest Margin with Sovereign Risk

\begin{tabular}{|c|c|c|c|c|c|c|}
\hline & \multicolumn{6}{|c|}{ Net Interest Margin (p.p.) } \\
\hline & \multicolumn{2}{|c|}{ All Banks } & \multicolumn{2}{|c|}{ Low } & \multicolumn{2}{|c|}{ High } \\
\hline & (1) & $(2)$ & (3) & (4) & (5) & (6) \\
\hline Lagged Dependent Variable & $\begin{array}{c}0.345^{* * *} \\
(5.14)\end{array}$ & $\begin{array}{c}0.340 * * * \\
(5.14)\end{array}$ & $\begin{array}{l}0.123 \\
(1.03)\end{array}$ & $\begin{array}{l}0.102 \\
(0.91)\end{array}$ & \begin{tabular}{|c}
$0.332 * * *$ \\
$(3.56)$
\end{tabular} & $\begin{array}{c}0.331^{* * *} \\
(3.57)\end{array}$ \\
\hline Deposits over Liablities (p.p.) & $\begin{array}{c}-0.00202 \\
(-1.66)\end{array}$ & $\begin{array}{c}-0.00155 \\
(-1.25)\end{array}$ & $\begin{array}{c}-0.00111 \\
(-0.32)\end{array}$ & $\begin{array}{c}0.00238 \\
(0.92)\end{array}$ & $\begin{array}{c}-0.00361 \\
(-1.30)\end{array}$ & $\begin{array}{c}-0.00374 \\
(-1.33)\end{array}$ \\
\hline Equity over Assets (p.p.) & $\begin{array}{c}0.0448 * * * \\
\quad(3.77)\end{array}$ & $\begin{array}{c}0.0463^{* * *} \\
\quad(4.06)\end{array}$ & $\begin{array}{c}0.0489 * * * \\
(4.10)\end{array}$ & $\begin{array}{c}0.0412^{* * *} \\
\quad(3.50)\end{array}$ & $\begin{array}{c}0.0378 * * \\
(2.53)\end{array}$ & $\begin{array}{c}0.0382 * * \\
(2.56)\end{array}$ \\
\hline Security over Assets (p.p.) & $\begin{array}{c}-0.00291 \\
(-1.48)\end{array}$ & $\begin{array}{c}-0.00272 \\
(-1.35)\end{array}$ & $\begin{array}{c}-0.00435^{* *} \\
(-2.38)\end{array}$ & $\begin{array}{c}-0.00317^{* *} \\
(-2.26)\end{array}$ & $\begin{array}{c}-0.00421 \\
(-1.26)\end{array}$ & $\begin{array}{c}-0.00446 \\
(-1.29)\end{array}$ \\
\hline GDP Growth (p.p.) & $\begin{array}{c}-0.00104 \\
(-0.47)\end{array}$ & $\begin{array}{c}-0.000822 \\
(-0.40)\end{array}$ & $\begin{array}{c}-0.0000993 \\
(-0.03)\end{array}$ & $\begin{array}{c}0.00107 \\
(0.27)\end{array}$ & $\begin{array}{l}-0.00113 \\
(-0.13)\end{array}$ & $\begin{array}{c}-0.00141 \\
(-0.16)\end{array}$ \\
\hline 3-Month Sovereign Yield (p.p.) & $\begin{array}{c}0.0567 * * \\
(2.23)\end{array}$ & $\begin{array}{c}0.0736 * * \\
(2.64)\end{array}$ & $\begin{array}{c}0.158^{* *} \\
(2.12)\end{array}$ & $\begin{array}{c}0.146 * * \\
(2.45)\end{array}$ & $\begin{array}{l}0.0216 \\
(0.58)\end{array}$ & $\begin{array}{c}0.0370 \\
(0.88)\end{array}$ \\
\hline Spread: 10yr - 3mo Yield (p.p.) & $\begin{array}{c}0.00774 \\
(0.12)\end{array}$ & $\begin{array}{c}0.0412 \\
(0.62)\end{array}$ & $\begin{array}{c}0.143^{* *} \\
(2.58)\end{array}$ & $\begin{array}{c}0.114 * * * \\
(3.24)\end{array}$ & $\begin{array}{l}-0.0577 \\
(-1.12)\end{array}$ & $\begin{array}{c}-0.0320 \\
(-0.51)\end{array}$ \\
\hline Sovereign CDS & & $\begin{array}{c}-0.000254^{* *} \\
(-2.04)\end{array}$ & ! & $\begin{array}{c}-0.00167^{* * *} \\
(-7.31)\end{array}$ & $\begin{array}{l}1 \\
1 \\
1 \\
1\end{array}$ & $\begin{array}{c}-0.000109 \\
(-1.26)\end{array}$ \\
\hline Fixed Effects: & & & | & & l & \\
\hline Bank & $\checkmark$ & $\checkmark$ & $\checkmark$ & $\checkmark$ & $\checkmark$ & $\checkmark$ \\
\hline Constant & $\begin{array}{c}1.366 * * * \\
(8.75)\end{array}$ & $\begin{array}{c}1.259 * * * \\
(7.17)\end{array}$ & $\begin{array}{c}1.368^{* *} \\
(2.81)\end{array}$ & $\begin{array}{c}1.283^{* * *} \\
(3.62)\end{array}$ & $\begin{array}{c}2.005^{* * *} \\
(7.22)\end{array}$ & $\begin{array}{c}1.946^{* * *} \\
(6.83)\end{array}$ \\
\hline Observations & 23,472 & 23,472 & 14,084 & 14,084 & 9,388 & 9,388 \\
\hline Banks & 2,967 & 2,967 & 2,660 & 2,660 & 2,404 & 2,404 \\
\hline
\end{tabular}

Notes: Our base sample includes 2,967 banks from 40 countries from 2005 to 2013. Unconsolidated bank-level balance sheets and income statements are reported by Bankscope. Interest rates are calculated as the annual average of daily implied sovereign yields reported by Bloomberg, and Sovereign CDS is the annual average of daily 5-year sovereign CDS spreads. Columns (1) and (2) include all observations, Columns (3) and (4) include only those observations in a Low yield environment, where the 3-month sovereign yield is at or below 1.25 percent, and Columns (5) and (6) include only those observations in a High yield environment, where the 3-month sovereign yield is above 1.25 percents. Standard errors are clustered at the country level and tstatistics are reported in parentheses. All regressions include bank fixed-effects. 